NBER WORKING PAPER SERIES

\title{
UNIVERSITIES, JOINT VENTURES AND SUCCESS IN THE ADVANCED TECHNOLOGY PROGRAM
}

\author{
Michael R. Darby \\ Lynne G. Zucker \\ Andrew Wang \\ Working Paper 9463 \\ http://www.nber.org/papers/w9463
NATIONAL BUREAU OF ECONOMIC RESEARCH 1050 Massachusetts Avenue
Cambridge, MA 02138
January 2003

This is a revision of a paper presented at the Western Economic Association International 77th Annual Meetings, Seattle, Washington, June 30, 2002. We thank the University of California's Industry-University Cooperative Research Program, and especially its Director, Dr. Susanne L. Huttner, for providing support for licenses to limited use data and development of a "fuzzy matching" algorithm. This support provided for both the data in IPR/UCLA Archive as well as the ability to match ATP participant companies into it. We thank Adam Jaffe for advance access to the Hall, Jaffe, and Tratjenberg (2001) patent data through 1996 and Linda Cohen for thoughtful advice through multiple revisions. We are indebted to a remarkably talented UCLA research team, especially David Johnson, Wenjin Kang, Qiao Liu, David Waguespak, and Xiaogang $\mathrm{Wu}$, and also Stephanie Hwang, Andrew Jing, Henry Tang, and Mo Xiao. This paper is a part of the NBER's research program in Productivity. Any opinions expressed are those of the authors and not those of the National Bureau of Economic Research, the University of California, or the U.S. Department of Commerce. The views expressed herein are those of the authors and not necessarily those of the National Bureau of Economic Research.

(C2003 by Michael R. Darby, Lynne G. Zucker and Andrew Wang. All rights reserved. Short sections of text not to exceed two paragraphs, may be quoted without explicit permission provided that full credit including notice, is given to the source. 
Universities, Joint Ventures, and Success in the Advanced Technology Program

Michael R. Darby, Lynne G. Zucker, and Andrew Wang

NBER Working Paper No. 9462

January 2003

JEL No. R21, E21, G11, G12, J14

\section{$\underline{\text { ABSTRACT }}$}

America's most innovative firms participate in the U.S. Commerce Department's Advanced Technology Program (ATP) - those that participated at least once accounted for over 40 percent of U.S. patents to U.S. entities during 1988-1996. Many firms are repeat participants. ATP participation has significant and robust effects on innovation in firms, generally increasing firms' patenting during the time they are receiving ATP support, when compared to patenting by the same firms prior to and after the ATP award. ATP participation increases firms' patenting on average by between 5 and 30 patents per year during the period of ATP participation. This represents a 4 to 25 percent increase in firms' patenting compared to the period before ATP participation. Furthermore, joint-venture (JV) project participation and university participation in a project both appear to have a positive impact on firm patenting. The amount of funding received by the firm is crucial for single participants, with the positive impact concentrated in those firms with large grants. Single participants are more likely than JV members to be small startups for which ATP funding is large relative to the total R\&D budget. For JV participants, participation is more important than the level of funding.

Michael R. Darby

Cordner Professor of Money \& Financial Markets Depts. of Management, Economics \& Policy Studies Anderson Graduate School of Management University of California, Los Angeles

Los Angeles, CA 90095-1481

and NBER

darby@ucla.edu

Andrew Wang

Senior Economist

Office of Economic Assessment

Advanced Technology Program

National Institute of Standards and Technology

Gaithersburg, MD 20899

Andrew.Wang@,nist.gov
Lynne G. Zucker, Professor of Sociology \&

Director, Center for International Science, Technology, and Cultural Policy School of Public Policy \& Social Research University of California, Los Angeles Los Angeles, CA 90095-1551 and NBER zucker@ucla.edu 


\section{UNIVERSITIES, JOINT VENTURES, AND SUCCESS \\ IN THE ADVANCED TECHNOLOGY PROGRAM}

\section{MICHAEL R. DARBY, LYNNE G. ZUCKER, and ANDREW WANG}

\section{Introduction}

The Advanced Technology Program (ATP), at the National Institute for Standards and Technology (NIST), aims to fund enabling technologies which firms are not likely to pursue in a timely way without the ATP. The role of the Advanced Technology Program (ATP) is to "bridge" the gap from demonstrating a promising but risky idea to garnering the organizational resources to commercialize a product. In doing so, the ATP increases the prospect of commercial capture of advanced technology. NIST made its first awards in 1990, based on peer-reviewed proposals submitted by either individual firms or joint ventures of two or more collaborating firms. Over its ten-year history, ATP has managed over 1000 participants and subcontractors.

A necessary (but not sufficient) condition for the success of the Advanced Technology Program is that it contributes to the success of participant firms: If the participant firms do not benefit from the new technology, others are unlikely to adopt it. Hence, as a first step, we search for evidence of ATP's overall impact on firm success. Our second step is to investigate what might explain any impact on firm success that we may discover. We consider the effect of program design. ATP makes two types of awards - for projects that explicitly involve collaboration between two or more firms (and also possibly other organizations such as universities and federal laboratories); and for projects proposed by individual firms, with no formal collaborative framework. The former we term joint venture or JV projects, and the latter we call single participant or SP projects. Our study examines the effects on firms related to these project structure differences, and also related to participation by universities (as a full member in a JV, or as a subcontractor in either an SP or JV project).

We evaluate ATP's effects in terms of overall change in successful patent applications during the period of ATP support. Patents are a useful measure of innovation for all ATP 
participants: small, privately held firms; larger public firms; universities; and other research organizations. During the period 1988 to 1996, firms and organizations that participated in ATP accounted for over $40 \%$ of all patents granted to U.S. entities by the U.S. Patent and Trademark Office (USPTO). Firms comprise $88 \%$ of the total number of all ATP participants, and account for over $80 \%$ of all patents awarded to ATP participants. Innovation in "advanced technology" and patenting appear to go hand-in-hand for nearly all of the firms and organizations participating in ATP. This concentration of technological progress in relatively few firms is the stressed by Harberger (1998) and Darby and Zucker (2003).

In our view, ATP not only provides funding awards to participants, but also promotes "institution-building" in the process, encouraging applicants to establish new organizational structures that facilitate innovation and the capture of inventions in technologically advanced commercial products. Institution-building takes place in ATP in a number of ways. First, ATP supports firms willing to experiment and develop approaches that are novel and at the technological frontier. ATP stimulates industry to initiate projects that are higher in risk, with greater potential for broader economic impact. Second, ATP encourages cooperation and collaboration in R\&D activities, among JV partners, and also through subcontracting relationships with universities, firms, and other organizations. Linkages that are important to innovation and to technology transfer among firms/organizations are emphasized by ATP in selecting projects initially, and then also in project review and monitoring activities.

In social science terminology, the ATP project changes participants' "social embeddedness" in networks of relations with other firms and organizations. While this effect may be especially prominent for Joint Venture participants, firms in Single Participant projects also note the importance of R\&D subcontractors and relationships for achieving project objectives. To the extent that ATP project participation enhances firms' social network for R\&D, we expect that the impact on innovation outcomes will extend beyond the project level to the firm level. Therefore, we assess the impact of ATP at the firm level in a 'before' and 'after' 
comparison of firm-level innovation outcomes.

The next section develops the analysis of ATP program design as institution building. Section III lays out the methodology of our empirical analysis, focusing particularly on panel design and sampling criteria and variable construction. The main empirical results are reported in Section IV where we estimate the overall and separate effects of participation and funding amount on the rate of patenting by program participants. Conclusions are drawn in Section V. Beginning at page 32 after the main body of the paper is a technical appendix which elaborates on methodology, data, and estimates.

\section{ATP Program Design as Institution-Building}

The "social embeddedness" perspective on economic behavior of individuals and firms emphasizes the social context and interactions of economic actors. In traditional economic theory, economic behavior is analyzed in terms of rational choice and utility-maximizing individuals or profit-maximizing firms, and relatively little emphasis is placed on specific historical and social context. Sociologists on the other hand have emphasized the importance of understanding how specific social relationships shape economic behavior and economic outcomes. Economic behavior is embedded in a social context, and the characteristics of particular social relations affect economic behavior and determine economic outcomes. Granovetter (1985) provides a number of useful examples. When disputes arise in business, they are "frequently settled without reference to the contract or potential or actual legal sanctions." Instead, personal relationships based on cooperation and trust are important to solving problems and reaching agreements. Or when firms subcontract, or make sales or purchasing decisions, long-term sustained relationships between firms are often built on ongoing social interactions or networks.

When ATP makes an award and funds a project, the participating firms and other organizations establish R\&D and business ties, thus extending and enhancing their social network for innovation. By fostering organizational interactions, ATP builds the institutional 
basis for innovation. From their networks, firms gain access to knowledge and complementary expertise of R\&D partners, as well as business and marketing resources of partner firms. The social embeddedness perspective on R\&D and innovation emphasizes that ATP project participation is a conscious institution-building process - firms partner under the ATP to establish R\&D structures that are favorable to high-risk research, and conducive to socially beneficial behaviors such as research cooperation and information sharing, in joint ventures and in university collaborations for example.

We highlight a few types of social embeddedness - social relations that alter economic behavior and outcomes - that are particularly important aspects of ATP's institution-building:

- Close contact among researchers in collaborative R\&D work. Such relationships are most likely to transmit novel knowledge that is close to the knowledge frontier and hence often tacit in nature (Zucker, Darby, and Armstrong 1998).

- Relaxation of boundaries around the firm, permitted because information gains are expected to be sufficiently valuable to the firm to offset any losses (Zucker et al. 1996). The boundary permeability allows more flow of information and hence more learning across organizations than would otherwise be the case. Boundary design is often part of the strategic arsenal of a firm (Helper, MacDuffie, and Sabel 2000).

- Development of institution-based trust that rests on institutional structures rather than interpersonal or specific characteristics of the other party (Zucker 1986). Two examples of institution-based trust provided for by ATP include: (a) Third-party (ATP) monitoring of participants' behavior in Joint Ventures to ensure cooperation (see Zucker et al. 1996); and (b) Administrative structures and agreements (e.g., intellectual property agreements, JV administrative structures) to increase confidence in successful coordination (see Das and Teng 1998).

We believe that the implicit design of ATP encourages firms to relax their boundaries and share knowledge. Actors will contribute more to a collective good when they believe their 
action is likely to have efficacy, and when there are norms of fairness that encourage them to match the contributions of others (Gould 1993). ATP provides an institutional structure and mechanisms that makes efficacy and "fairness" more likely. The gains from research collaboration derive from resource exchange in complementary capabilities, information, financial resources, and access to particular technologies or science base. ATP provides opportunities for firms (and other organizations) to collaborate and realize these potential gains. Firms participating in ATP gain from the project, learn from each other, and become better at innovating.

ATP institution-building is also evident in ATP guidelines for design of projects and structuring of partners to produce greater research synergy. For example, ATP encourages a mix of JV partners in order to further prospects for R\&D success and technology commercialization and diffusion: "Joint ventures should aim to include companies of diverse size, including smaller companies, and possibly other organizations, such as universities and national laboratories" (ATP 1999: 34). And many ATP projects involve universities. Since universities are often at the center of new discoveries and their application, particularly discoveries that involve radical change from prior knowledge (see Zucker and Darby 1996; Zucker, Darby and Brewer 1998; Liebeskind et al. 1996; also Jaffe 1989), university relationships may be a key source of information for many ATP projects.

ATP has a goal of encouraging collaborations among firms, and between firms and universities and other organizations (federal labs, independent research institutes) in the U.S. innovation system. ATP encourages formation of JVs, providing potentially higher award levels and more years of funding, and encourages JV members to establish governance structures for internal management of JVs. ATP's suggestions for design of JVs tends to relax the boundaries of participants' organizations. ATP in effect opens up boundaries where the ATP project impinges, encouraging joint governance and reasonable access by all JV members to intellectual property created within the JV. "Spillovers" or transfers of knowledge to other JV members occur within this 
enlarged "information envelope" that protects information dissemination (Zucker et al. 1996). In particular, internal task routines that are difficult to understand from outside of organizations may be transferred (see Nelson and Winter 1982: 123-124).

Enlarging effective organizational boundaries to encompass new research collaborations has two main effects that cause more information sharing to occur: (1) JVs make knowledge created by one participant organization more observable to the other participants, since internal task routines that are often unobservable across organizational boundaries become transparent through joint work among scientists, engineers, and other technically trained workers; and (2) boundary enlargement may define a new "commons," an area of mutual benefit around the shared ATP project, which may draw in additional shared resources as research effort progresses or shows promise.

Our argument is that JV participants, because of ATP's institution-building process and reinforcing project management oversight, operate in — are "embedded in" — a different social context or new social structure when they enter a new JV through an ATP award. By becoming embedded in the new structure, JV participants derive an informational or knowledge benefit. The firms not only have more financial resources through ATP funding, but also have changed social relationships (more collaborators and different collaborators, and more intense collaborations). These relationships provide intellectual capital, and social contacts that add value through learning processes that result in information or knowledge transfer (Hamel 1991; Doz 1996). Many JVs, for example, come together specifically to apply for ATP funding, and bring together firms that have not worked together before.

Comments by ATP participants in JVs support our argument. As one JV member notes: "Excellent collaborative environment and complementary technical capabilities have improved the quality of technical output and effectiveness of the team. There has been tremendous synergy between the companies that are collaborating on this project. Each company brings a particular expertise that the others don't have and which would be difficult to develop. Each party is an enabler for the others" (Powell and Lellock 2000: 23). Another JV participant states: "Exposed 
to new ideas, technologies that would otherwise not have been exposed to. Enabled us to leap forward with newer approaches into our architectural design." For projects that involve collaboration, $97 \%$ of participants report that the collaboration stimulated creative thinking, and $86 \%$ report that the collaboration allowed them to obtain R\&D expertise (Powell and Lellock 2000: 20). (See Appendix Figure A2 for additional detail on intellectual property strategies.)

The new JV learning context also includes firms, universities, federal labs, and organizations outside of the JV, organizations which JV partners collaborate with or are linked to in some way. These connections multiply access to other kinds of knowledge, which provides additional expanded information advantage (see Granovetter 1973, on the strength of weak ties in social networks). As one JV member explains: "In general, the collaboration has allowed us to contact new potential collaborators and markets. Some of these markets are for new equipment using our technology in ways we had not considered. Due to the success of the JV, the various members are investigating projects outside the ATP" (Powell and Lellock 2000: 25).

\section{Methods}

Institution-building by ATP and the resulting organizational and informational advantages held by ATP participants are factors that enter into the innovation process in ATP projects. How do we best measure the impact? To assess changes in organizational learning and knowledge through ATP projects, we will study change in innovation outcomes, comparing 'before' and 'after' ATP. A major purpose of ATP is to increase commercial capture of advanced technology. Patents are arguably the single best measure of commercial capture of invention, conveying intellectual property rights. Patents are in fact commonly used to protect intellectual property created under ATP support: $76 \%$ of organizations report that patenting is a primary or secondary strategy for intellectual property, with only $12 \%$ reporting that patenting is unlikely (Powell and Lellock 2000: 43).

In the analysis to follow, we assess whether ATP projects have a general effect on formation of new intellectual property within the firm. While an ATP project may represent only 
one R\&D effort among many at a firm, to the extent that ATP changes firm behavior, institutional setting, or social embeddedness, the impact of the ATP project may extend beyond the project to affect the firm more generally. Our key indicator of impact on firm innovation is whether the overall rate of patenting by a firm increases after participation in ATP begins. We focus on project structure (Joint Venture vs. Single Participant), and university participation (university partner in a JV project, and university subcontractor in a JV or SP project). We use a patent count measure based on archival data assembled by Hall, Jaffe, and Tratjenberg (2001) and significantly augmented by the Center for International Science, Technology, and Cultural Policy (CISTCP) at UCLA.

Our first step is to set the unit of analysis. Archival data on patents are generally available only for the firm or organization as a whole, and not for specific locations of multilocation firms. Our analysis of whether participation in ATP has a positive effect on firms is therefore centered on the firm/organization as the basic unit of analysis. Figure 1 shows the number of ATP projects and firm participants from ATP award years 1990-1998. Figure 2 shows the distribution by SP or JV type for projects and all participants, from ATP award years 19901998. The number of single firm projects is about twice the number of joint venture projects. But because joint ventures involve multiple participants, the number of JV participants is more than twice the number of SP participants. Some firms/organizations have participated in more than one ATP project, and some have been in both JV and SP projects. More detailed description of the data is included in the Technical Appendix.

Many ATP participants work with university scientists. Figure 3 shows that nearly three quarters of unique ATP firm participants have had university partners or subcontractors. Figure 4 shows the distribution of firms by technology area and type of university participation. We establish a hierarchy to define firm participants as JV or SP, with or without university partner. If a firm has been a full partner in a JV project from ATP award years 1990-1998, then it is considered to be a "JV firm." JV firms that have had a university as a JV partner or sub- 
contractor in this period are defined as "JV firm - university partner and subcontractor." JV firms that have had only a university JV partner or only a university subcontractor are defined as "JV firm - university partner" or "JV firm - university subcontractor." The remaining JV firms are "JV firm - no university." Single participant firms are classified as either "SP firm university subcontractor" or "SP firm - no university."

\section{A. Sampling Criteria and Panel Design}

Patenting by ATP-awardee firms is tracked before, during, and after they become ATP participants, allowing us to assess patenting performance for periods with and without ATP support. ATP participant firms can therefore serve as their own comparison group.

For our analysis we include all firms involved in $R \& D$ in projects that started by the end of 1995. (We exclude some participants involved only in administrative functions, and participants involved only in projects cancelled before completion.) Firms enter our analysis panel in the year the firm was founded, or in the first year of our panel, 1988, if the firm was founded before 1988. We chose 1988 as the first year for the panel to allow for pre-ATP observation years even for firms entering in the first ATP cohort (1991). The panel ends in 1996 because number of patents dated by year of application is our key variable of interest, and by 1997 the count of patents by year of application becomes truncated because many patent applications from 1997 have yet to emerge from the patent process, given that our patents granted data ends June 30, 1999.

Table 1 presents the panel structure for the two samples of firms. In order to match patent data, multiple establishments of the same firm are counted as one unit, even though different locations of a firm may be participating at different times in ATP. The first sample (panel A) is all firms that have participated in ATP, and the second sample (panel B) is publicly traded firms that have participated in ATP. New entrants to the panel, in years other than the first year of the panel, are due to founding of a new firm. Table 2 shows the distribution of firms by size category. 


\section{B. Variable Construction}

Our analysis of ATP impact is based on measurement of changes in patenting success by firms during and after participation in ATP. The overall rate of patenting depends on the "propensity to patent," which is affected by the value of getting a patent and the ease of obtaining a patent (Griliches, 1990). In recent years, Congress and the courts have strengthened patent rights, and the U.S. Patent and Trademark Office has hired more patent examiners. As a result, both the rate of patent application and the speed with which patents are granted have increased. A simple before and after comparison of patenting is therefore subject to criticism as reflecting trend increases in patenting rather than identifying real program impact. Accordingly, we develop a "deflated" patent-count measure, which adjusts for year to year changes in the average rate of patenting, measured by average number of "patents per assignee" for all U.S. assignees of U.S. patents.

All dollar amounts (i.e., ATP award amounts and company cost-share amounts, as well as R\&D expenditures for public firms) are deflated to 1996 dollars using the Chain-Type Price Index for Gross Domestic Product. We construct an R\&D stock variable to measure the cumulated "R\&D capital" of the firm. Annual R\&D expenditures are available for public firms from the Compustat database. Annual R\&D expenditures are cumulated and discounted to produce the $R \& D$ stock variable.

Table 3 provides descriptive statistics for the variables used in the empirical analysis for three groups of ATP participants: (1) All firm participants; (2) Public firm participants, defined as firms appearing in the Compustat database; and (3) All organization participants, including universities and other non-profits in JV projects.

The firm size categories used are based on ATP definitions of firm size. The industry sector categories are based on ATP definitions of the technology area of the ATP project. These industry categories refer to the technology area of the ATP project, and are not comparable to the more typical SIC codes. 


\section{Empirical Results: ATP's Effects on Firm Success}

\section{A. Effects of ATP Participation on Patenting}

Our basic hypotheses concern the effects of ATP participation on patenting. First, we hypothesize that participation in ATP projects has a positive effect on patenting at the firm level, that is, that the benefit of ATP project participation extends beyond the project to the firm level. Second, we hypothesize that participation in JV projects provides greater benefit to firms than participation in Single Participant projects, so we expect the ATP participation effect on firm patenting to be greater for firms in JVs. The argument is that JV membership expands and deepens connections among organizations, which is "social capital" for firm innovation. Third, we hypothesize that the effect of ATP participation on innovation, as measured by firm patenting, is greater if the firm has a university partner or subcontractor. This hypothesis derives from studies that have shown the importance of academe to science-driven industries (Zucker and Darby 1996, 1998; Zucker, Darby, and Brewer 1998; Zucker, Darby, and Armstrong 1998; Jensen and Thursby 2001; Thursby and Thursby 2002).

We now turn to our main analysis of the panel of all firms that began participation in ATP by the end of 1995. In Table 4, we control for firm size and project technology area, and then include dummy variables which describe firms' type of ATP participation in each year. In regression 4.1, we see that ATP participation is associated with an increase by 29 in number of patents awarded to the firm. An increase of 29 patents represents close to a $75 \%$ increase in patenting relative to the mean number of patents per year for firms in the sample. In regression 4.2, we see that ATP Joint Venture project participation has a positive effect relative to Single Participant project participation. In regression 4.3, we see that Joint Ventures with a university partner receive an additional positive effect on patenting, and in regression 4.4 , we see that university subcontractors have a positive effect on firm patenting. We conclude that Joint Venture participation and university participation are important to higher rates of patenting by firms in ATP projects. 


\section{B. Separate Effects of Participation and Funding Amount}

We can extend our analysis by taking into account the total amount of ATP award funds received, and also the amount received through JV project awards. In this case, the degree or extent of ATP participation (or the intensity of the ATP "treatment effect") is indicated by the amount of ATP award funding received by the firm. Following typical practice, we cumulate these funds over time, incorporating a $20 \%$ per year depreciation rate, to create an ATP award stock variable. For firms that have participated only in JV projects, the total award stock and JV award stock variables will be equal, while for firms that have participated in both SP and JV projects, the total award stock variable will sometimes be greater than the JV award stock variable. The measured effect on patenting of an additional dollar of SP award funding is equal to the coefficient on the total award stock variable, while the measured effect on patenting of an additional dollar of JV award funding is equal to the sum of the coefficients on the total award stock and JV award stock variables.

Table 5 reports results for regressions that include size and industry controls, ATP participation and JV participation variables, ATP award stock and JV award stock variables, and several university involvement variables. Interpreting the regression results is somewhat complicated. First, estimates for the effect of ATP participation on patenting must be presented by specific category of participant (e.g. JV with university partner) at the sample mean for the category. Second, because the ATP award stock variable is a stock variable, the effect of participation persists beyond the period of active participation. In Figures 5 and 6, the left bar in each pair in Figures 5 and 6 presents a conservative interpretation of regression 5.4 by showing the estimated increase in patenting during the sample period for the indicated groups. (The estimates of patenting increases per year of participation are computed by multiplying the relevant coefficients for ATP participation and award stocks by the sample means for each of the specified groups, summing the results, and dividing by the mean number of years of participation.) The estimate is conservative in that only about one third of the full effect from the 
award-stock variables occurs within the sample period. Even under this conservative approach, we estimate that the average ATP participant firm increases its patenting by 34 patents per year of ATP participation during the sample period. Thus, even without allowing for the future effects of the knowledge created under the ATP program, we find a very substantial effect on patenting with one quarter of these firms' patents during 1988-1996 attributable to ATP participation. There is also evidence that the effect on patenting is greater for those firms that partner with universities during their ATP participation.

Table 6 and the right bar in each pair in Figures 5 and 6 present results from similar regressions with fixed effects for each firm instead of industry and size dummies to control for unobserved heterogeneity. We find an average increase in patenting by 6 patents per year of ATP participation during the sample period. This amounts to $4 \%$ of these firms' patenting over the entire sample period including all the years from 1988 until they began participating in ATP.

Tables 7 and 8 and the corresponding Figures 7 and 8 present results from similar regressions for the subsample of firms that are publicly traded. For these firms we have data to compute a cumulative R\&D stock variable in the same way as the ATP award stock variable. For these publicly traded firms, the regular and fixed-effect regressions produce estimates of increase in patents by 19 patents and 5 patents per year of ATP participation during the sample period.

\section{Conclusions and Implications}

We find that patenting generally increases after ATP participation under a number of different program and participant variations. ATP participation increases patenting on average by between 5 and 30 patents per firm per year of participation, which represents a 4 to 25 percent increase in firms' patenting compared to the period before ATP participation. These estimates are conservative since future effects from the ATP project participation are not included, even though they are implied in our regression models. Also, joint-venture project participation and university participation in a project both appear to have a positive impact on firm patenting. The findings of this study support the idea that joint ventures and university collaboration have a 
positive impact on innovation.

Positive effects of ATP on innovation in participating companies are significant and robust in the analyses we report in this paper. Our measure of innovation - firm patents - suggests that the effect of the ATP project spreads beyond the project and has impact on the entire firm. We may interpret this result as evidence that ATP project participation supports firm-wide behavioral or organizational changes which foster an increased rate innovation. Alternatively, "internal spillovers" of knowledge or other benefits from one project to other projects may also help explain the broad firm-wide effects of ATP participation.

This study considers the effect of program design — project structure and university participation - on the innovation success of firm participants. The findings indicate that joint venture collaboration and university participation have positive effect on innovation outcomes as measured by patents. These results are interpreted from a sociological perspective that emphasizes institution-building and social relations as essential to the innovation process. From this perspective, ATP as a public-private partnership program fills a role in fostering the institutions and social processes that facilitate innovation. 


\section{REFERENCES}

Advanced Technology Program. Proposal Preparation Kit. Gaithersburg, MD: National Institute of Standards and Technology, November 1999.

Darby, M. R., and L. G. Zucker. "Growing by Leaps and Inches: Creative Destruction, Real Cost Reduction, and Inching Up.” Economic Inquiry, 41(1), 2003, 1-19.

Das, T. K., and B.-S. Teng. "Between Trust and Control: Developing Confidence in Partner Cooperation in Alliances." Academy of Management Review, 23(3), 1998, 491-512.

Doz, Y. L. "The Evolution of Cooperation in Strategic Alliances: Initial Conditions or Learning Processes?" Strategic Management Journal, 17, 1996, 55-83.

Gould, R. V. "Collective Action and Network Structure." American Sociological Review, 58(2), 1993, 182-196.

Granovetter, M. "The Strength of Weak Ties.” American Journal of Sociology, 78(6), 1973, 1360-1380.

Granovetter, M. "Economic Action and Social Structure: The Problem of Embeddedness." American Journal of Sociology, 91(3), 1985, 481-510.

Griliches, Z. "Patent Statistics as Economic Indicators: A Survey." Journal of Economic Literature, 28(4), 1990, 1661-1707.

Hall, B. H., A. B. Jaffe, and M. Tratjenberg. "The NBER Patent Citation Data File: Lessons, Insights and Methodological Tools." National Bureau of Economic Research Working Paper 8498, October 2001. [Online database at http://www.nber.org/patents/]

Hamel, G. "Competition for Competence and Inter-Partner Learning within International Strategic Alliances." Strategic Management Journal, 12(special issue), 1991, 83-103.

Harberger, A. C. "A Vision of the Growth Process." American Economic Rev, 88(1), 1998, 1-32.

Helper, S., J. P. MacDuffie, and C. Sabel, "Pragmatic Collaborations: Advancing Knowledge while Controlling Opportunism." Industrial and Corporate Change, 9(3), 2000, 443-87.

Jaffe, A. B. "Real Effects of Academic Research." American Economic Rev., 79(5), 1989, 957-970. 
Jensen, R., and M. Thursby. "Proofs and Prototypes for Sale: The Tale of University Licensing." American Economic Review, 91(1), 2001, 240-59.

Liebeskind, J. P., A. L. Oliver, L. G. Zucker, and M. B. Brewer. "Social Networks, Learning, and Flexibility: Sourcing Scientific Knowledge in New Biotechnology Firms." Organization Science, 7(4), 1996, 428-443.

Nelson, R. R., and S. G. Winter. An Evolutionary Theory of Economic Change. Cambridge, MA: The Belknap Press of Harvard University Press, 1982.

Powell, J. W., and K. L. Lellock. Development, Commercialization, and Diffusion of Enabling Technologies: Progress Report. Gaithersburg, MD: National Institute of Standards and Technology, April 2000.

Thursby, J. G., and M. Thursby. "Who Is Selling the Ivory Tower? Sources of Growth in University Licensing.” Management Science, 48(1), 2002, 90-104.

Zucker, L. G. "Production of Trust: Institutional Sources of Economic Structure, 1840-1920." Research in Organizational Behavior, 8, 1986, 53-111.

Zucker, L. G., and M. R. Darby. "Star Scientists and Institutional Transformation: Patterns of Invention and Innovation in the Formation of the Biotechnology Industry." Proceedings of the National Academy of Sciences, 93(23), 1996, 12,709-12,716.

Zucker, L. G., and M. R. Darby. "Capturing Technological Opportunity Via Japan's Star Scientists: Evidence from Japanese Firms' Biotech Patents and Products." Journal of Technology Transfer, 26(1/2), 2001, 37-58.

Zucker, L. G., M. R. Darby, and J. Armstrong. "Geographically Localized Knowledge: Spillovers or Markets?" Economic Inquiry, 36(1), 1998, 65-86.

Zucker, L. G., M. R. Darby, and M. B. Brewer. "Intellectual Human Capital and the Birth of U.S. Biotechnology Enterprises." American Economic Review, 88(1), 1998, 290-306.

Zucker, L. G., M. R. Darby, M. B. Brewer, and Y. Peng. "Collaboration Structure and Information Dilemmas in Biotechnology: Organizational Boundaries as Trust Production," in Trust in 
Organizations, edited by Roderick M. Kramer and Tom R. Tyler, Thousand Oaks, CA: Sage, 1996, 90-113. 
TABLE 1

Number of Companies Actively Participating in ATP by Panel Year

A. All Companies

\begin{tabular}{lccccccccc}
\hline Year & 1988 & 1989 & 1990 & 1991 & 1992 & 1993 & 1994 & 1995 & 1996 \\
\hline Total Organizations & 232 & 245 & 260 & 274 & 285 & 349 & 349 & 350 & 350 \\
Entrants to Panel & 232 & 13 & 15 & 14 & 11 & 64 & 0 & 1 & 0 \\
Active in ATP & 0 & 0 & 0 & 20 & 71 & 90 & 117 & 341 & 319 \\
Inactive in ATP & 232 & 245 & 260 & 254 & 214 & 259 & 232 & 9 & 31 \\
\hline
\end{tabular}

B. Public Companies Only ${ }^{\mathrm{a}}$

\begin{tabular}{lccccccccc}
\hline Year & 1988 & 1989 & 1990 & 1991 & 1992 & 1993 & 1994 & 1995 & 1996 \\
\hline Total Organizations & 93 & 96 & 99 & 108 & 116 & 122 & 131 & 151 & 151 \\
Entrants to Panel & 93 & 3 & 3 & 9 & 8 & 7 & 9 & 21 & 4 \\
Firms Exiting Panel $^{\mathrm{b}}$ & 0 & 0 & 0 & 1 & 0 & 0 & 1 & 1 & 4 \\
Active in ATP & 0 & 0 & 0 & 6 & 36 & 45 & 56 & 149 & 137 \\
Inactive in ATP $^{9}$ & 93 & 96 & 99 & 102 & 80 & 77 & 75 & 2 & 14 \\
\hline
\end{tabular}

${ }^{a}$ Public is defined as appearing in the COMPUSTAT files.

${ }^{\mathbf{b}}$ These firms did not have R\&D expenditures reported in COMPUSTAT for the indicated years.

TABLE 2

ATP Firm Participants by Size

\begin{tabular}{lcccc} 
& \multicolumn{2}{c}{ All Firms } & \multicolumn{2}{c}{ Public Firms } \\
& Freq. & $\%$ & \multicolumn{2}{c}{$\mathrm{N}=158$} \\
& & & & \\
& 195 & 55.7 & 57 & 36.1 \\
Small $^{\mathbf{a}}$ & 88 & 25.1 & 47 & 29.7 \\
Medium $^{\mathbf{b}}$ & 67 & 19.1 & 54 & 34.2
\end{tabular}

${ }^{\mathrm{a}} \mathrm{Small}=$ less than 500 employees.

${ }^{\mathbf{b}}$ Medium $=500$ or more employees, but less than Fortune 500 or equivalent.

${ }^{c}$ Large $=$ Fortune 500 or equivalent 
TABLE 3

Descriptive Statistics for Regression Sample of ATP Firms

\begin{tabular}{|c|c|c|c|c|}
\hline \multirow[b]{2}{*}{ Variable } & \multicolumn{2}{|c|}{$\frac{\text { All Firms }}{N=2694}$} & \multicolumn{2}{|c|}{$\begin{array}{c}\text { Public Firms } \\
\mathrm{N}=1067\end{array}$} \\
\hline & Mean & S. D. & Mean & S. D. \\
\hline \multicolumn{5}{|l|}{ DEPENDENT VARIABLE } \\
\hline Patents, deflated $^{\mathrm{e}}$ & 39.35 & 141.83 & 87.37 & 206.93 \\
\hline \multicolumn{5}{|l|}{ ATP PARTICIPATION INDICATORS } \\
\hline ATP participant ${ }^{\mathrm{b}}$ & 0.29 & 0.42 & 0.33 & 0.44 \\
\hline ATP JV participant ${ }^{b}$ & 0.20 & 0.37 & 0.26 & 0.42 \\
\hline JV with university partner ${ }^{\mathrm{b}}$ & 0.08 & 0.26 & 0.12 & 0.31 \\
\hline JV with university subcontractor ${ }^{\mathrm{b}}$ & 0.11 & 0.29 & 0.14 & 0.32 \\
\hline SP with university subcontractor ${ }^{b}$ & 0.07 & 0.24 & 0.08 & 0.25 \\
\hline Cumulative ATP award stock $(\$ 000 \mathrm{~s})^{\mathrm{a}}$ & 272.39 & 748.74 & 389.78 & 1020.57 \\
\hline Cumulative ATP JV award stock $(\$ 000 \mathrm{~s})^{\mathrm{a}}$ & 132.59 & 543.65 & 229.55 & 773.68 \\
\hline \multicolumn{5}{|l|}{ EIRM CHARACTERISTICS } \\
\hline Small Firm ${ }^{c}$ & 0.50 & 0.50 & 0.25 & 0.44 \\
\hline Medium Firm $^{c}$ & 0.28 & 0.45 & 0.32 & 0.47 \\
\hline Large Firm $^{\mathrm{c}}$ & 0.22 & 0.41 & 0.43 & 0.49 \\
\hline Biotechnology ${ }^{\mathrm{d}}$ & 0.13 & 0.32 & 0.11 & 0.30 \\
\hline Chemicals $^{\mathrm{d}}$ & 0.07 & 0.24 & 0.11 & 0.28 \\
\hline Electronics ${ }^{\mathrm{d}}$ & 0.14 & 0.32 & 0.14 & 0.30 \\
\hline Energy $^{\mathrm{d}}$ & 0.04 & 0.18 & 0.05 & 0.19 \\
\hline Information Technology ${ }^{d}$ & 0.23 & 0.41 & 0.21 & 0.39 \\
\hline Manufacturing $^{\mathrm{d}}$ & 0.22 & 0.40 & 0.20 & 0.37 \\
\hline Materials ${ }^{\mathrm{d}}$ & 0.17 & 0.35 & 0.18 & 0.34 \\
\hline Cumulative R\&D stock (\$millions) $^{\mathrm{e}}$ & $\mathrm{n} / \mathrm{a}$ & $\mathrm{n} / \mathrm{a}$ & 1759.78 & 4605.06 \\
\hline
\end{tabular}

${ }^{\mathrm{a}}$ Continuous variable for firm-year: Sum of monthly pro-rated award amount for firm in year.

${ }^{\mathrm{b}}$ Numerical fraction variable for firm year: (Number of months during year where indicator true)/12.

${ }^{c}$ Dummy variable for firm (does not vary by year): Size of firm $[0,1]$.

${ }^{\mathrm{d}}$ Numerical fraction variable for firm-year: Technology area of ATP project; numerical fraction when firm is in more than one project and technology areas of projects differ.

${ }^{\mathrm{e}}$ Continuous variable for firm-year. 
TABLE 4

Patenting by Type of ATP Participation, All Firms - OLS Regression

\begin{tabular}{|c|c|c|c|c|}
\hline \multirow{3}{*}{$\begin{array}{l}\text { Dependent Variable } \\
\text { Specification } \\
\text { Estimation }\end{array}$} & \multicolumn{4}{|c|}{ Patents, by date of application (deflated, one year lag) } \\
\hline & 4.1 & 4.2 & 4.3 & 4.4 \\
\hline & OLS & OLS & OLS & OLS \\
\hline \multirow[t]{2}{*}{ Constant } & $-50.718 * * *$ & $-50.561 * * *$ & $-48.298 * * *$ & $-50.300 * * *$ \\
\hline & $(10.936)$ & $(10.896)$ & $(10.897)$ & $(10.753)$ \\
\hline \multirow[t]{2}{*}{ Small firm } & $-13.225 *$ & -10.952 & -10.303 & -9.924 \\
\hline & $(5.770)$ & $(5.770)$ & $(5.762)$ & $(5.681)$ \\
\hline \multirow[t]{2}{*}{ Large firm } & $156.503 * * *$ & $154.309 * * *$ & $153.634 * * *$ & $149.691 * * *$ \\
\hline & $(7.021)$ & $(7.011)$ & $(7.001)$ & $(6.916)$ \\
\hline \multirow[t]{2}{*}{ Biotechnology } & $55.545 * * *$ & $57.723 * * *$ & $53.647 * * *$ & $59.946 * * *$ \\
\hline & $(12.382)$ & $(12.345)$ & $(12.384)$ & $(12.233)$ \\
\hline \multirow[t]{2}{*}{ Electronics } & $99.215 * * *$ & $98.965 * * *$ & $99.200 * * *$ & $102.851 * * *$ \\
\hline & $(12.176)$ & $(12.130)$ & $(12.108)$ & $(12.023)$ \\
\hline \multirow[t]{2}{*}{ Energy And Environment } & $50.194 * *$ & $54.170 * * *$ & $53.145 * * *$ & $52.123 * * *$ \\
\hline & $(16.643)$ & $(16.604)$ & $(16.576)$ & $(16.350)$ \\
\hline \multirow[t]{2}{*}{ Info./Comp./Comm./Ent. System } & $58.400 * * *$ & $58.643 * * *$ & $54.854 * * *$ & $59.365 * * *$ \\
\hline & $(11.095)$ & $(11.054)$ & $(11.093)$ & $(10.954)$ \\
\hline \multirow[t]{2}{*}{ Manufacturing (Discrete) } & $41.138 * * *$ & $37.514 * * *$ & $34.262 * *$ & $35.801 * * *$ \\
\hline & $(11.180)$ & $(11.166)$ & $(11.189)$ & $(11.031)$ \\
\hline \multirow[t]{2}{*}{ Materials } & $50.952 * * *$ & $49.001 * * *$ & $47.263 * * *$ & $48.703 * * *$ \\
\hline & $(11.831)$ & $(11.795)$ & $(11.785)$ & $(11.628)$ \\
\hline \multirow[t]{2}{*}{ ATP participant } & $28.867 * * *$ & -4.844 & -4.980 & $-70.538 * * *$ \\
\hline & $(5.701)$ & $(9.279)$ & $(9.262)$ & $(12.422)$ \\
\hline \multirow[t]{2}{*}{ ATP JV participant } & & $48.334 * * *$ & $31.871 * *$ & $68.127 * * *$ \\
\hline & & $(10.520)$ & $(11.625)$ & $(15.131)$ \\
\hline \multirow[t]{2}{*}{ JV with university partner } & & & $38.438 * * *$ & $26.327 *$ \\
\hline & & & $(11.645)$ & $(11.579)$ \\
\hline \multirow[t]{2}{*}{ JV with university subcontractor } & & & & $47.057 * * *$ \\
\hline & & & & $(11.545)$ \\
\hline \multirow[t]{2}{*}{ SP with university subcontractor } & & & & $101.406 * * *$ \\
\hline & & & & $(13.210)$ \\
\hline Adjusted R-squared & $0.239 * * *$ & $0.245 * * *$ & $0.247 * * *$ & $0.269 * * *$ \\
\hline $\mathrm{N}$ & 2694 & 2694 & 2694 & 2694 \\
\hline
\end{tabular}

Significance levels: $* \mathrm{p} \leq .05, * * \mathrm{p} \leq .01, * * * \mathrm{p} \leq .001$ 
TABLE 5

Patenting by All Firms: Intensity of ATP Project Participation - OLS Regression

\begin{tabular}{|c|c|c|c|c|}
\hline \multirow{3}{*}{$\begin{array}{l}\text { Dependent Variable } \\
\text { Specification } \\
\text { Estimation }\end{array}$} & \multicolumn{4}{|c|}{ Patents, by date of application (deflated, one year lag) } \\
\hline & 5.1 & 5.2 & 5.3 & 5.4 \\
\hline & OLS & OLS & OLS & OLS \\
\hline Constant & $\begin{array}{c}-46.904 * * * \\
(10.960)\end{array}$ & $\begin{array}{c}-41.265 * * * \\
(10.511)\end{array}$ & $\begin{array}{c}-40.674 * * * \\
(10.399)\end{array}$ & $\begin{array}{c}-40.404 * * * \\
(10.399)\end{array}$ \\
\hline Small firm & $\begin{array}{c}-11.907^{*} \\
(5.790)\end{array}$ & $\begin{array}{c}-14.556 * * \\
(5.536)\end{array}$ & $\begin{array}{c}-12.329 * \\
(5.498)\end{array}$ & $\begin{array}{c}-11.577^{*} \\
(5.483)\end{array}$ \\
\hline Large firm & $\begin{array}{c}159.125^{* * *} \\
(7.034)\end{array}$ & $\begin{array}{c}143.168^{* * * *} \\
(6.792)\end{array}$ & $\begin{array}{c}139.682 * * * \\
(6.740)\end{array}$ & $\begin{array}{c}138.768 * * * \\
(6.720)\end{array}$ \\
\hline Biotechnology & $\begin{array}{c}59.906 * * * \\
(12.408)\end{array}$ & $\begin{array}{c}46.164 * * * \\
(11.895)\end{array}$ & $\begin{array}{c}48.746 * * * \\
(11.776)\end{array}$ & $\begin{array}{c}48.063 * * * \\
(11.835)\end{array}$ \\
\hline Electronics & $\begin{array}{c}104.810^{* * * *} \\
(12.181)\end{array}$ & $\begin{array}{c}79.819^{* * *} \\
(11.750)\end{array}$ & $\begin{array}{c}77.738^{* * * *} \\
(11.629)\end{array}$ & $\begin{array}{c}82.578^{* * * *} \\
(11.689)\end{array}$ \\
\hline Energy And Environment & $\begin{array}{c}53.224 * * * \\
(16.709)\end{array}$ & $\begin{array}{l}38.722 * \\
(15.985)\end{array}$ & $\begin{array}{c}42.009 * * \\
(15.836)\end{array}$ & $\begin{array}{c}42.248 * * \\
(15.789)\end{array}$ \\
\hline Info./Comp./Comm./Ent. System & $\begin{array}{c}61.732 * * * \\
(11.127)\end{array}$ & $\begin{array}{c}52.236^{* * *} \\
(10.652)\end{array}$ & $\begin{array}{c}51.705^{* * *} \\
(10.540)\end{array}$ & $\begin{array}{c}50.649 * * * \\
(10.587)\end{array}$ \\
\hline Manufacturing (Discrete) & $\begin{array}{c}44.145^{* * * *} \\
(11.215)\end{array}$ & $\begin{array}{c}40.375^{* * * *} \\
(10.726)\end{array}$ & $\begin{array}{c}35.867 * * * \\
(10.639)\end{array}$ & $\begin{array}{l}33.421 * * \\
(10.644)\end{array}$ \\
\hline Materials & $\begin{array}{c}52.779 * * * \\
(11.880)\end{array}$ & $\begin{array}{c}45.644 * * * \\
(11.356)\end{array}$ & $\begin{array}{c}42.447 * * * \\
(11.244)\end{array}$ & $\begin{array}{c}42.398 * * * \\
(11.228)\end{array}$ \\
\hline ATP participant & & $\begin{array}{c}-20.843 * * * \\
(6.365)\end{array}$ & $\begin{array}{c}-95.280 * * * \\
(11.485)\end{array}$ & $\begin{array}{c}-104.890 * * * \\
(12.840)\end{array}$ \\
\hline $\begin{array}{l}\text { Cumulative ATP award stock, } \\
\text { (20\% annual depreciation, } \$ 000 \text { s) }\end{array}$ & & $\begin{array}{c}0.056^{* * *} \\
(0.004)\end{array}$ & $\begin{array}{c}0.090^{* * *} \\
(0.007)\end{array}$ & $\begin{array}{c}0.083 * * * \\
(0.008)\end{array}$ \\
\hline ATP JV participant & & & $\begin{array}{l}97.561 * * * \\
(12.632)\end{array}$ & $\begin{array}{l}76.474 * * * \\
(15.751)\end{array}$ \\
\hline $\begin{array}{l}\text { Cumulative ATP JV award stock, } \\
\text { (20\% annual depreciation, } \$ 000 \mathrm{~s})\end{array}$ & & & $\begin{array}{c}-0.051 * * * \\
(0.010)\end{array}$ & $\begin{array}{c}-0.045^{* * *} \\
(0.010)\end{array}$ \\
\hline JV with university partner & & & & $\begin{array}{l}31.973 * * \\
(11.208)\end{array}$ \\
\hline JV with university subcontractor & & & & $\begin{array}{l}30.554 * * \\
(11.254)\end{array}$ \\
\hline SP with university subcontractor & & & & $\begin{array}{c}26.104 \\
(14.008)\end{array}$ \\
\hline $\begin{array}{l}\text { Adjusted R-squared } \\
\mathrm{N}\end{array}$ & $\begin{array}{l}0.232 * * * \\
2694\end{array}$ & $\begin{array}{l}0.300 * * * \\
2694\end{array}$ & $\begin{array}{l}0.315 * * * \\
2694\end{array}$ & $\begin{array}{l}0.320 * * * \\
2694\end{array}$ \\
\hline
\end{tabular}

Significance levels: $* \mathrm{p} \leq .05, * * \mathrm{p} \leq .01, * * * \mathrm{p} \leq .001$ 
TABLE 6

Patenting by All Firms: Intensity of ATP Project Participation - Fixed Effects

Dependent Variable

Specification

Estimation

Constant

ATP participant

Cumulative ATP award stock, (20\% annual depreciation, \$000s)

ATP JV participant

Cumulative ATP JV award stock, (20\% annual depreciation, \$000s)

JV with university partner

JV with university subcontractor

SP with university subcontractor

Adjusted R-squared

$\mathrm{N}$

Significance levels: $* \mathrm{p} \leq .05, * * \mathrm{p} \leq .01, * * * \mathrm{p} \leq .001$
Patents, by date of application (deflated, one year lag)

$$
6.1
$$

Fixed effects

(1.087)

$-7.933 * *$

(2.617)

$0.012 * * *$

(0.002)
$38.381 * * *$
6.2

Fixed effects

$37.869 * * *$

(1.079)

$-26.099 * * *$

(4.924)

$0.033 * * *$

(0.003)

$21.791 * * *$

$(5.693)$

$-0.032 * * *$

(0.005)
6.3 Fixed effects

$37.815 * * *$

(1.081)

$-26.423 * * *$

(5.663)

$0.033^{* * *}$

$(0.004)$

$26.030 * * *$

(7.306)

$-0.032 * * *$

(0.005)

0.552

(5.366)

$-7.500$

(5.365)

0.680

(6.540)

$0.898 * * *$
2694

$0.898 * * *$

2694 


\section{TABLE 7}

Patenting by Public Firms: Intensity of ATP Project Participation - OLS Regression

Dependent Variable

\begin{tabular}{|c|c|c|c|c|}
\hline $\begin{array}{l}\text { Specification } \\
\text { Estimation }\end{array}$ & $\begin{array}{c}7.1 \\
\text { OLS }\end{array}$ & $\begin{array}{c}7.2 \\
\text { OLS }\end{array}$ & $\begin{array}{c}7.3 \\
\text { OLS }\end{array}$ & $\begin{array}{c}7.4 \\
\text { OLS }\end{array}$ \\
\hline Constant & $\begin{array}{c}-53.504 * * \\
(20.015)\end{array}$ & $\begin{array}{l}-47.167^{*} \\
(19.643)\end{array}$ & $\begin{array}{l}-46.005^{*} \\
(19.140)\end{array}$ & $\begin{array}{l}-46.186^{*} \\
(19.207)\end{array}$ \\
\hline Small firm & $\begin{array}{l}-14.990 \\
(13.098)\end{array}$ & $\begin{array}{l}-18.182 \\
(12.858)\end{array}$ & $\begin{array}{l}-18.858 \\
(12.562)\end{array}$ & $\begin{array}{l}-17.303 \\
(12.634)\end{array}$ \\
\hline Large firm & $\begin{array}{c}112.381^{* * * *} \\
(12.656)\end{array}$ & $\begin{array}{c}108.875 * * * \\
(12.371)\end{array}$ & $\begin{array}{c}105.712 * * * \\
(12.064)\end{array}$ & $\begin{array}{c}105.019 * * * \\
(12.062)\end{array}$ \\
\hline Biotechnology & $\begin{array}{l}75.316^{* *} \\
(23.841)\end{array}$ & $\begin{array}{c}66.516^{* *} \\
(23.371)\end{array}$ & $\begin{array}{c}75.078^{* * *} \\
(22.961)\end{array}$ & $\begin{array}{c}74.947 * * * \\
(23.085)\end{array}$ \\
\hline Electronics & $\begin{array}{c}168.140 * * * \\
(23.512)\end{array}$ & $\begin{array}{c}147.106 * * * \\
(23.240)\end{array}$ & $\begin{array}{c}142.296 * * * \\
(22.655)\end{array}$ & $\begin{array}{c}147.340 * * * \\
(22.927)\end{array}$ \\
\hline Energy And Environment & $\begin{array}{c}35.455 \\
(29.801)\end{array}$ & $\begin{array}{c}23.647 \\
(29.182)\end{array}$ & $\begin{array}{c}19.729 \\
(28.653)\end{array}$ & $\begin{array}{c}22.630 \\
(28.717)\end{array}$ \\
\hline Info./Comp./Comm./Ent. System & $\begin{array}{c}71.224 * * * \\
(20.245)\end{array}$ & $\begin{array}{c}68.329 * * * \\
(19.851)\end{array}$ & $\begin{array}{c}65.698 * * * \\
(19.346)\end{array}$ & $\begin{array}{c}66.442 * * * \\
(19.625)\end{array}$ \\
\hline Manufacturing (Discrete) & $\begin{array}{l}-4.701 \\
(20.553)\end{array}$ & $\begin{array}{l}-3.904 \\
(20.089)\end{array}$ & $\begin{array}{c}-5.763 \\
(19.582)\end{array}$ & $\begin{array}{l}-5.985 \\
(19.669)\end{array}$ \\
\hline Materials & $\begin{array}{l}54.413^{*} \\
(21.919)\end{array}$ & $\begin{array}{l}48.480^{*} \\
(21.429)\end{array}$ & $\begin{array}{l}42.785^{*} \\
(20.892)\end{array}$ & $\begin{array}{l}42.536^{*} \\
(20.905)\end{array}$ \\
\hline $\begin{array}{l}\text { Cumulative R\&D stock, } \\
\text { ( } 20 \% \text { annual depreciation, \$millions) }\end{array}$ & $\begin{array}{c}0.023 * * * \\
(0.001)\end{array}$ & $\begin{array}{c}0.021 * * * \\
(0.001)\end{array}$ & $\begin{array}{c}0.021 * * * \\
(0.001)\end{array}$ & $\begin{array}{c}0.021 * * * \\
(0.001)\end{array}$ \\
\hline ATP participant & & $\begin{array}{l}-28.738^{*} \\
(12.065)\end{array}$ & $\begin{array}{c}-133.849 * * * \\
(22.832)\end{array}$ & $\begin{array}{l}-152.559 * * * \\
(25.402)\end{array}$ \\
\hline $\begin{array}{l}\text { Cumulative ATP award stock, } \\
(20 \% \text { annual depreciation, } \$ 000 \text { s })\end{array}$ & & $\begin{array}{c}0.039 * * * \\
(0.005)\end{array}$ & $\begin{array}{c}0.110^{* * *} \\
(0.011)\end{array}$ & $\begin{array}{c}0.095^{* * *} \\
(0.013)\end{array}$ \\
\hline ATP JV participant & & & $\begin{array}{l}127.730^{* * *} \\
(24.264)\end{array}$ & $\begin{array}{c}132.109^{* * *} \\
(29.901)\end{array}$ \\
\hline $\begin{array}{l}\text { Cumulative ATP JV award stock, } \\
(20 \% \text { annual depreciation, } \$ 000 \mathrm{~s})\end{array}$ & & & $\begin{array}{l}-0.106 * * * \\
(0.014)\end{array}$ & $\begin{array}{l}-0.093 * * * \\
(0.016)\end{array}$ \\
\hline JV with university partner & & & & $\begin{array}{c}11.558 \\
(19.331)\end{array}$ \\
\hline JV with university subcontractor & & & & $\begin{array}{c}14.396 \\
(19.841)\end{array}$ \\
\hline SP with university subcontractor & & & & $\begin{array}{c}50.318 \\
(28.264)\end{array}$ \\
\hline Adjusted R-squared & $0.456 * * *$ & $0.481 * * *$ & $0.507 * * *$ & $0.508 * * *$ \\
\hline $\mathrm{N}$ & 1067 & 1067 & 1067 & 1067 \\
\hline
\end{tabular}

Patent application count for following year (for patents ultimately granted only), US patents/US assignees deflator

$7.1-7.2-7.3 \quad 7.4$

Significance levels: ${ }^{*} \mathrm{p} \leq .05, * * \mathrm{p} \leq .01, * * * \mathrm{p} \leq .001$ 
TABLE 8

Patenting by Public Firms: Intensity of ATP Project Participation - Fixed Effects

Dependent Variable

Specification

Estimation

Constant

Cumulative R\&D stock, (20\% annual depreciation, \$millions)

ATP participant

Cumulative ATP award stock, (20\% annual depreciation, $\$ 000$ s) ATP JV participant

Cumulative ATP JV award stock, (20\% annual depreciation, \$000s)

JV with university partner

JV with university subcontractor

SP with university subcontractor
Patent application count for following year (for patents ultimately granted only), US patents/US assignees deflator 8.1 Fixed effects $92.380 * * *$

(4.411)

$-0.004$

(0.002)

$-10.445$

(5.871)

$0.013 * * *$

(0.003)
8.3 Fixed effects
(4.588)

$-0.001$

(0.002)

$-21.368$

(13.797)

$0.049 * * *$

(0.007)
8.2 Fixed effects $85.931 * * *$

(4.510)

0.000

(0.002)

$-35.389 * *$

(11.792)

$0.044 * * *$

(0.006)

27.911*

(13.215)

$-0.048 * * *$

(0.009)

13.507

(17.088)

$-0.053^{* * *}$

(0.009)

20.598

(11.551)

$-12.424$

(11.280)

$-29.199$

(15.723)

Adjusted R-squared

$0.905 * * *$

1067

$0.908 * * *$

1067

$0.908 * * *$

1067

Significance levels: ${ }^{*} \mathrm{p} \leq .05,{ }^{* *} \mathrm{p} \leq .01,{ }^{* * *} \mathrm{p} \leq .001$ 


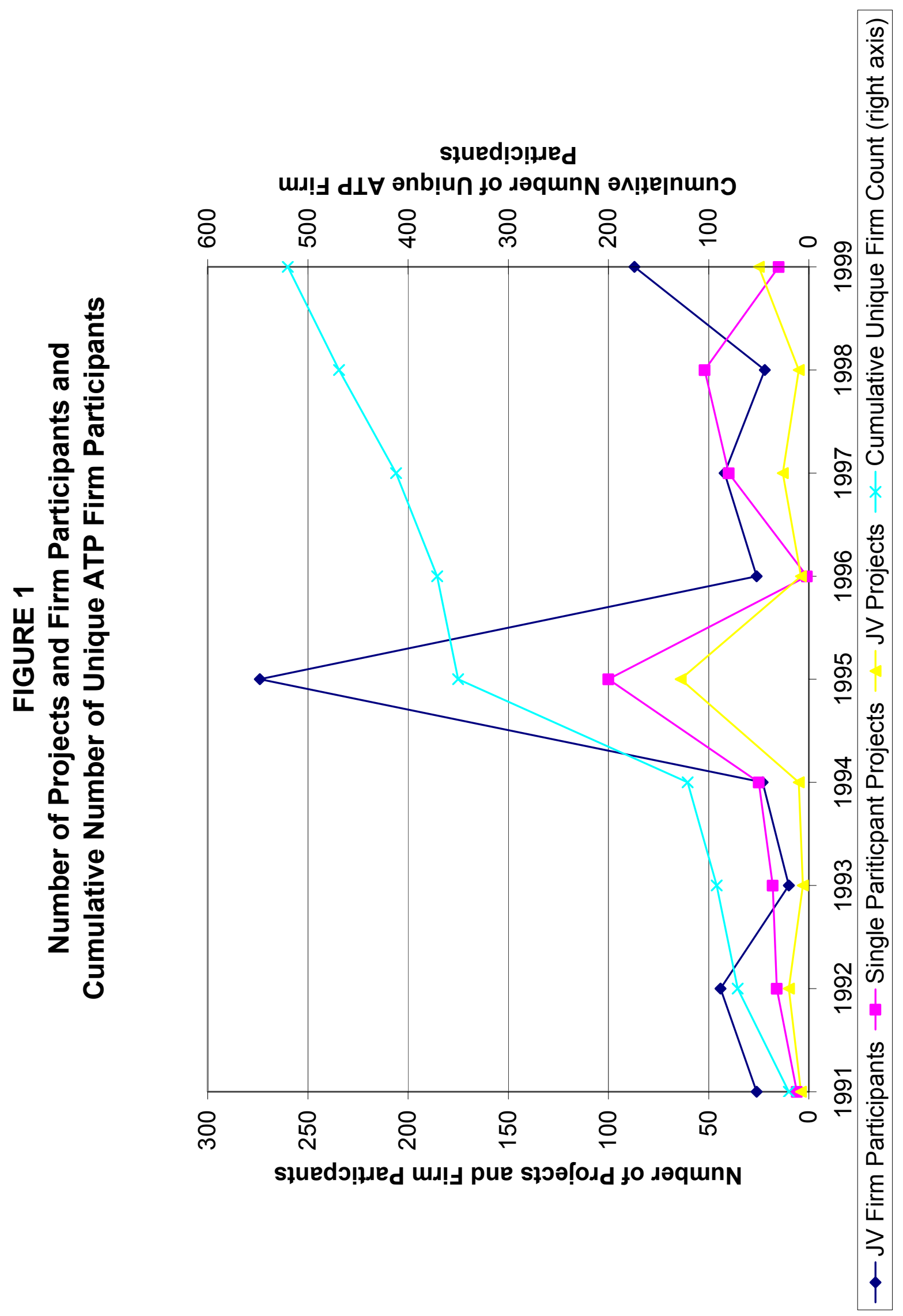




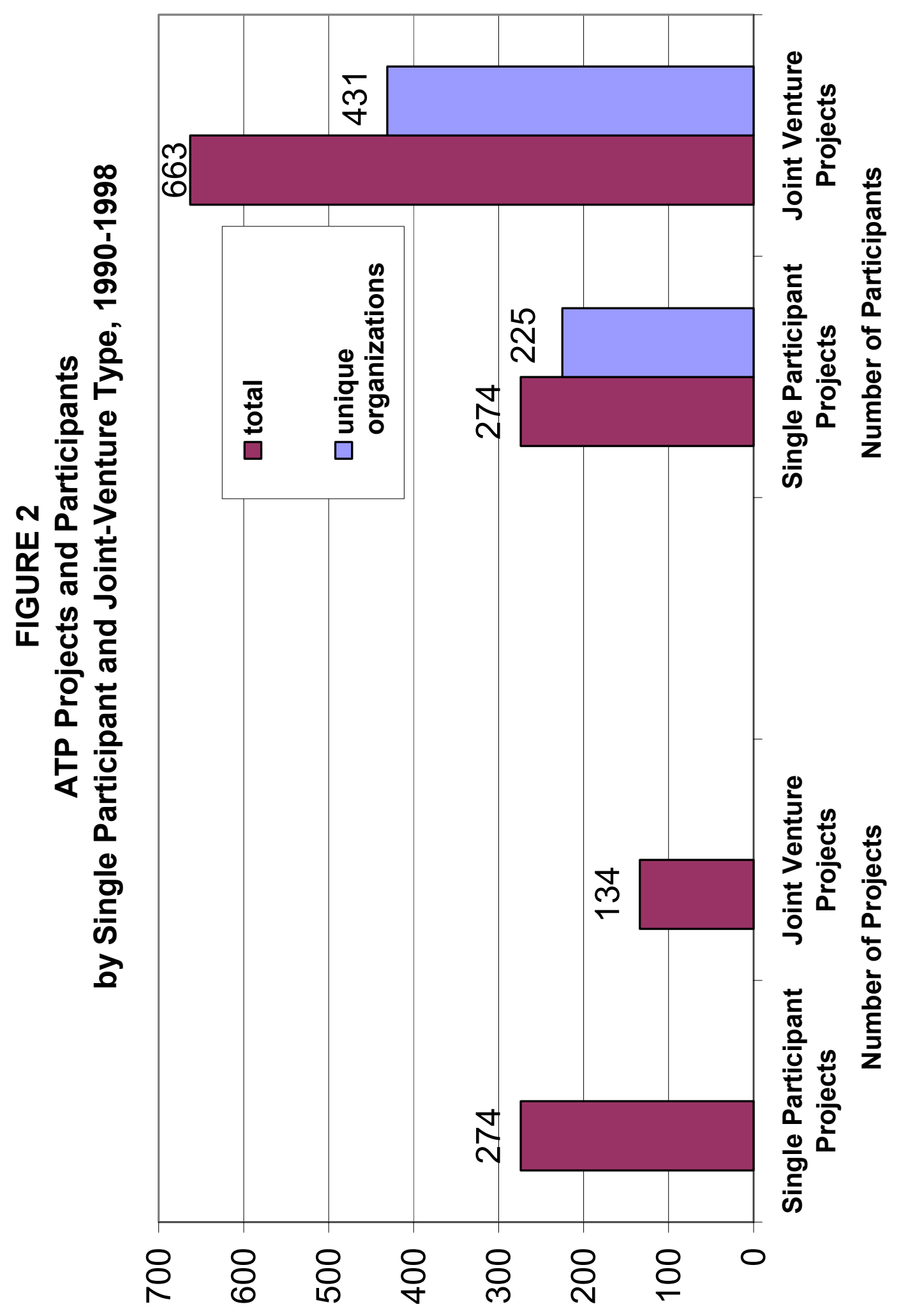




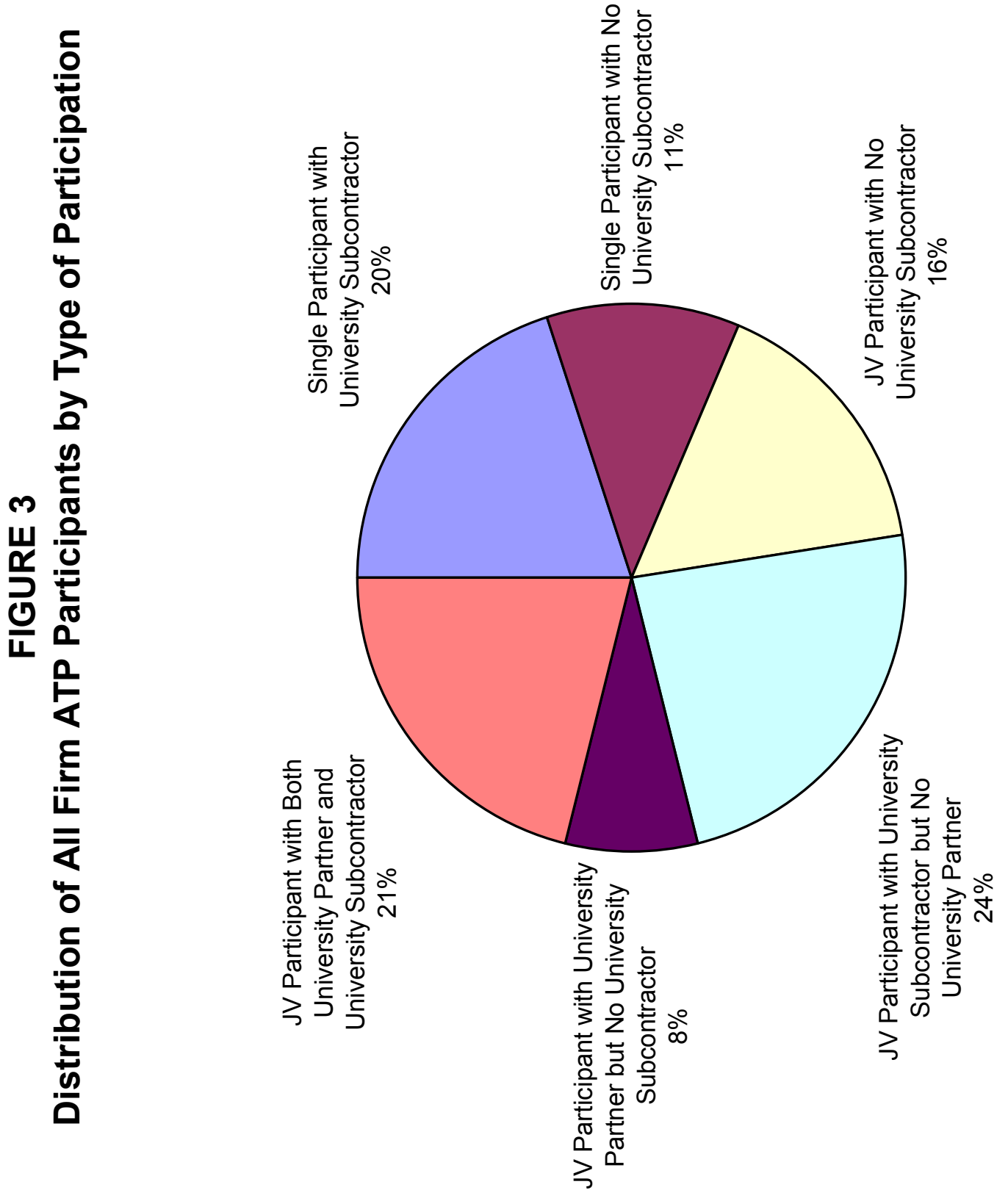




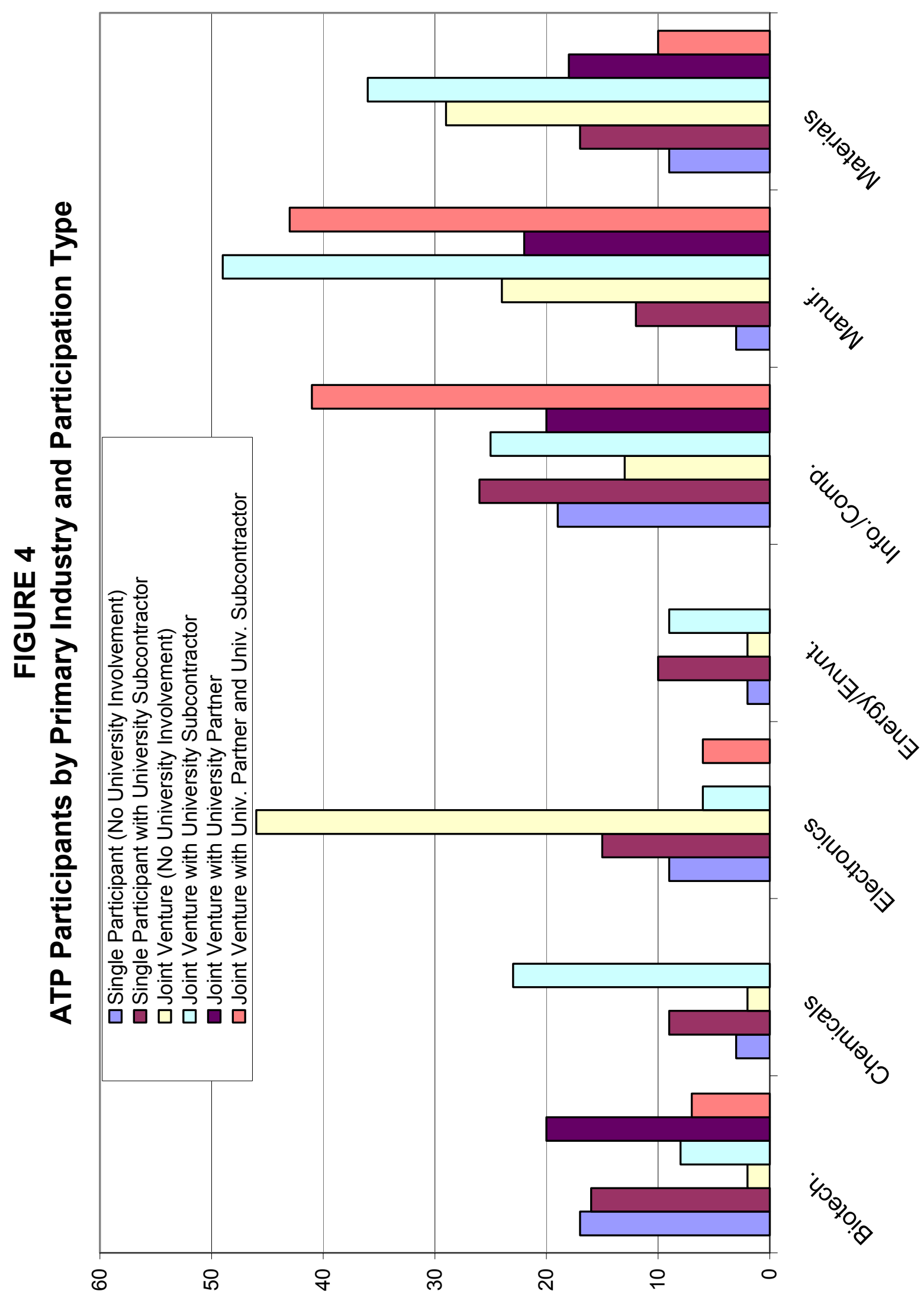




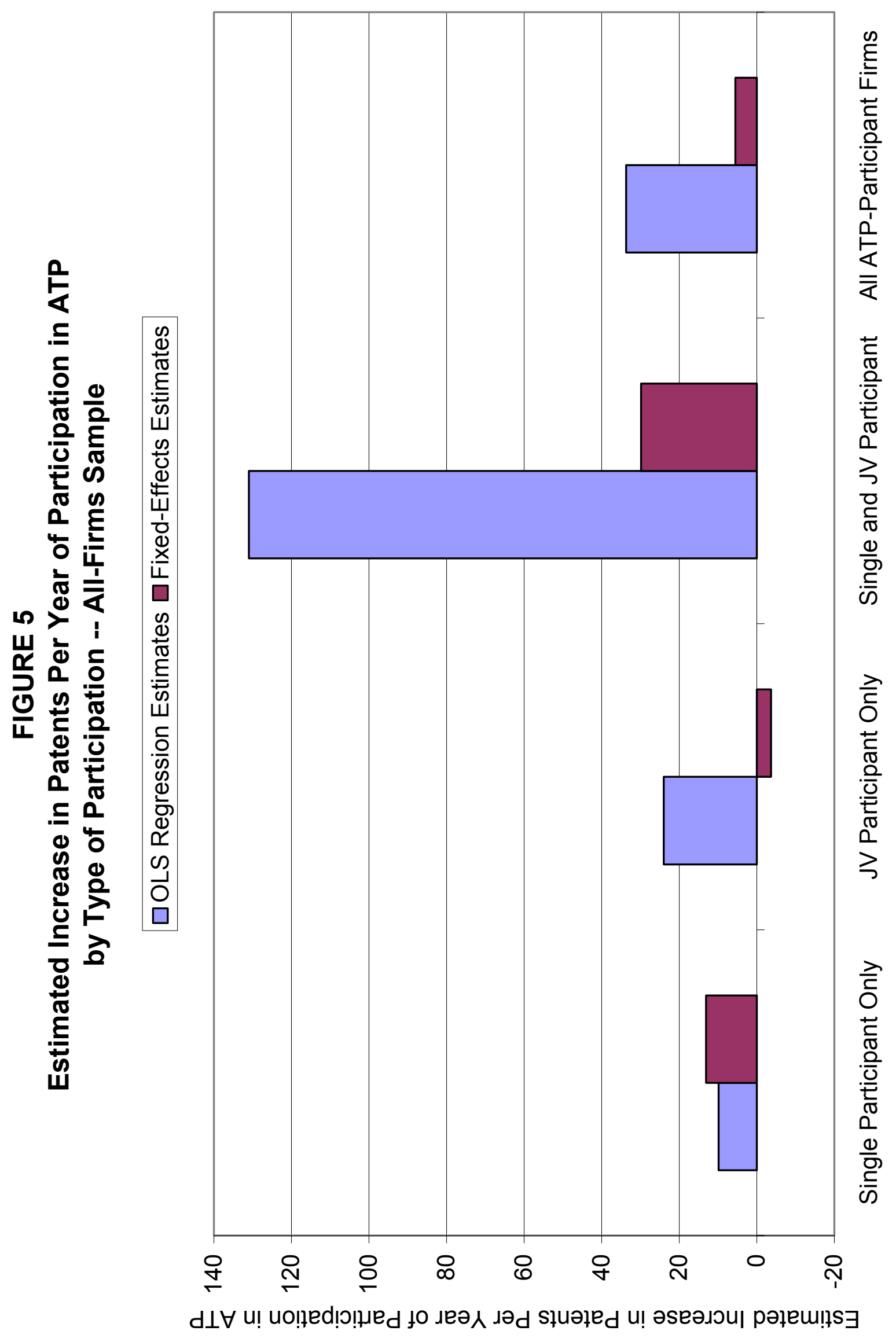




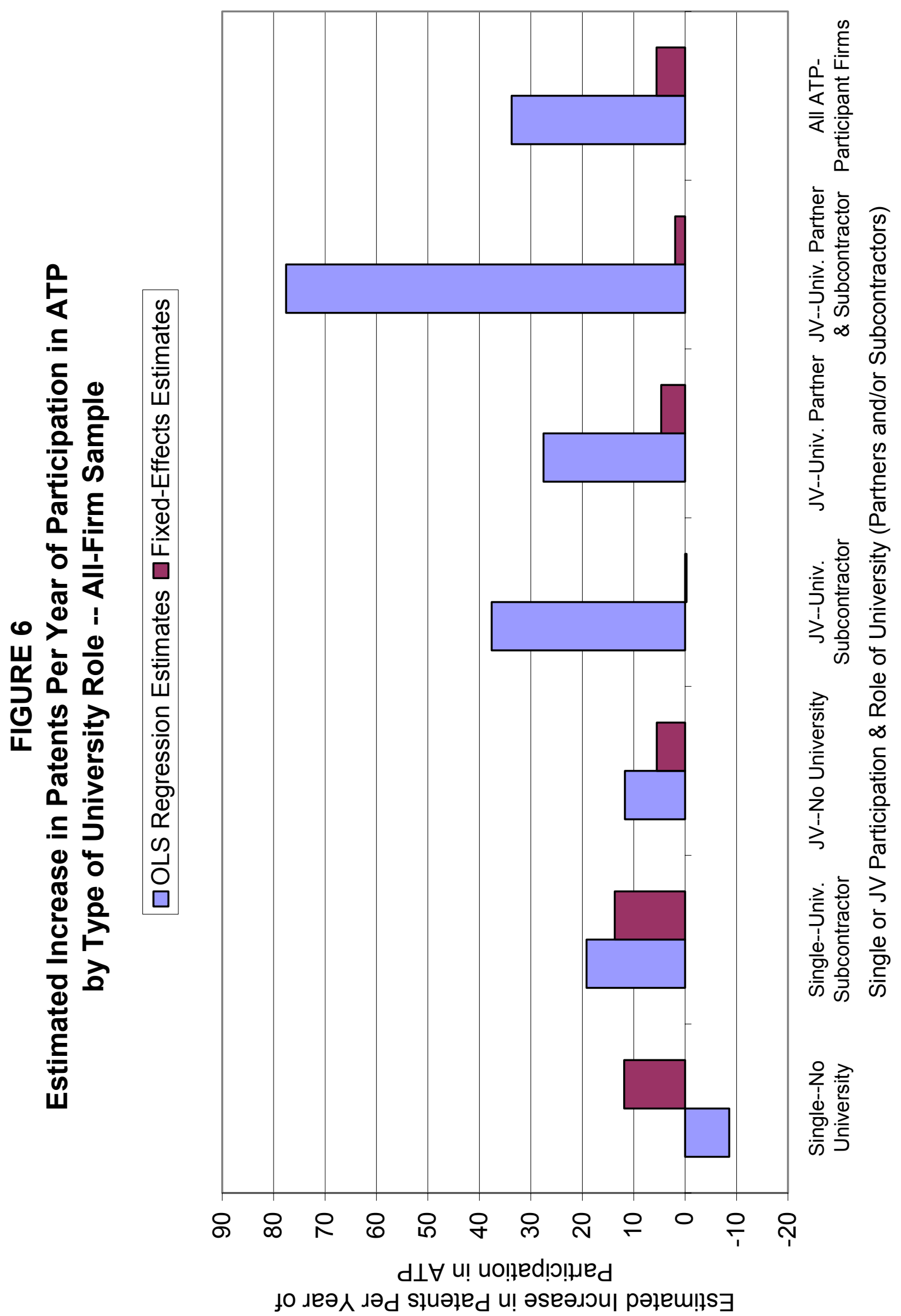




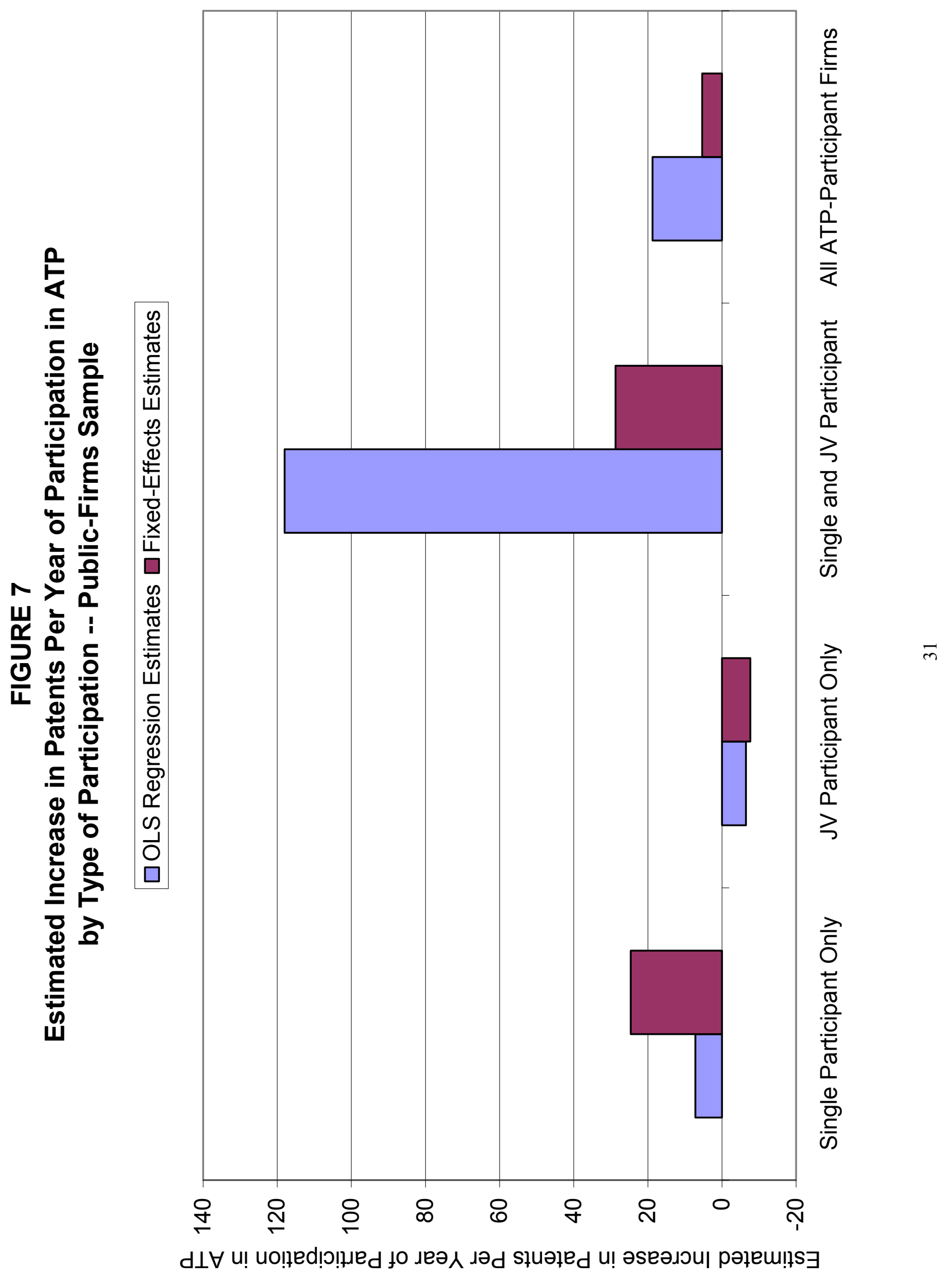




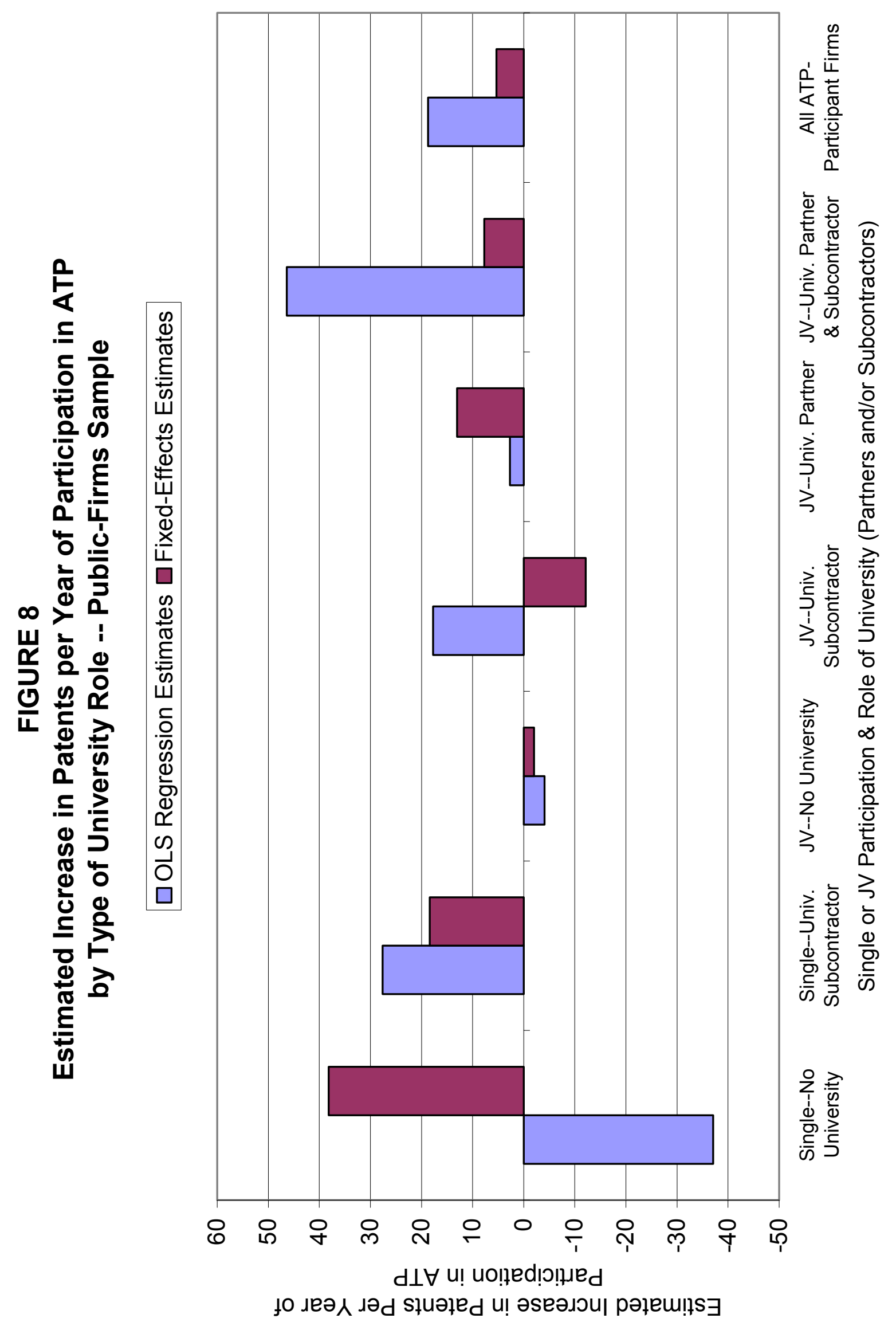




\section{TECHNICAL APPENDIX \\ FOR \\ UNIVERSITIES, JOINT VENTURES, AND SUCCESS \\ IN THE ADVANCED TECHNOLOGY PROGRAM \\ MICHAEL R. DARBY, LYNNE G. ZUCKER, and ANDREW WANG}

Contents of the Technical Appendix

A.1. Criteria for Inclusion in Sample and Construction of Industry Categories

A.2. Panel: Construction of the Panel and Integration of Merger/Acquisition \& Founding 36

A.3. Variable Construction

A.4. Data Sources

A.5. Additional Empirical Results

A.6. Additional References for the Technical Appendix 


\section{Technical Appendix}

We elaborate on five topics: (1) Criteria for inclusion in sample and technology areas; (2) Technical details on construction of the panel, including an overview of the panel construction process; (3) Variable construction; (4) Outline of data sources; and (5) Additional empirical results.

\section{A.1. Criteria for Inclusion in Sample and Construction of Industry Categories}

\section{Criteria for Inclusion in Sample}

Table A1 summarizes the criteria we used to select eligible participants. For our main analysis we selected firms only, because of the heterogeneity among non-profit ATP participants and the fact that all are in JVs. In Appendix A.5 below, we briefly examine all organizations that are ATP participants to check for potential bias in our results. Second, the ATP participant must be involved in research and development, excluding joint venture participants that served only administrative functions. Third, we exclude participants involved in projects that were cancelled before completion. Fourth, the project must have started by the end of 1996, in order to have multiple years of ATP participation for participants entering late in the period. Fifth, we determined year of founding for each firm (universities and other non-profits were assumed to be "born" by 1988 since there is no reliable data available). Firms enter the panel when founded or in 1988 if founded before that date in order to be able to distinguish whether no patenting in a given year meant that the organization did not yet exist or was in fact not patenting that year.

Sixth, still referring to Table A1, we selected 1988 as the starting observation year for firms already founded to provide some pre-ATP observations even for firms entering in the first ATP cohort (1991) and end the panel in 1996 because we use the number of patents, by year of 
application, for patents already granted (the US Patent and Trademark office releases no information on patents applied for but not yet granted). By 1997, the count of patent applications becomes truncated because many have yet to emerge from the process given that our patents granted data ends June 30, 1999.

Table A2 presents the number of organizations in the panel and whether or not they are active in ATP by year. This table corresponds to panel A of Table 1, with the difference between the two accounted for by universities and other non-profit organizations.

Construction of Industry Categories: Technology Area of ATP Project

As discussed in the text, when examining both public and privately held firms it is difficult to develop an industry code for the privately-held firms that will match, or even integrate well, with those customarily used for public firms. High technology industry codes, developed and used in the venture capital industry, do not mesh sufficiently well with SIC codes; industry categories available in data bases on public firms are not available for privately-held companies and have the additional problem of not sufficiently identifying sub-industry specialization across the firm. Further, universities do not have industry coding, though as partners in ATP JV projects or as subcontractors to either JV or SP projects universities play a significant role in firm success, as our results show. Accordingly, we used a common "workaround" by selecting the technology areas of the ATP projects as an industry proxy. The detailed categories are presented in Figure A1. We used the major bolded categories, except Z0000-Other which never appeared in the source data. ATP Participants: Intellectual Property Strategies Planned

Figure A2 presents additional detail on the distribution of intellectual property strategies planned by ATP participants. 


\section{A.2. Panel: Construction of the Panel and Integration of Merger/Acquisition \& Founding}

Our initial problem was to identify the "patenting entity" and organize the ATP information around that unit of analysis--not necessarily the same as the ATP participant name. If we found no patents for a particular ATP participant, we were challenged to determine whether it was a true zero or resulted from not tracing the appropriate patenting entity. In practice, we found corporate lineage sometimes quite difficult to trace; further, merger activity alters that relationship over time. Panel construction followed these steps:

Step 1: Identify the Unique Parent Organizations and Link to Patent Assignees

This step involved name cleaning and careful tracing of parent entities. We developed and implemented code to filter names and do fuzzy matching with U.S. patent assignees, followed by hand cleaning of the match results. We create a "variant to preferred" name list for each ATP participant, locating for example "Regents of the University of California" for the various UC campuses and associated federal laboratories.

Step 2: Link the ATP Organizations to Archival Firm Data and Refine "Patenting Entity"

Our refined list of "variant to preferred" names were then matched in to a very large data set of archival business information about US firms, including venture capital and new issues to cover both privately-held and public firms. These matches helped to identify additional variant names, leading to better selection of the preferred name for the firm.

Step 3: Determine the Birth Year for ATP "Patenting Entity"

An organization doesn't patent before it is founded, except under very unusual circumstances (working in a garage with a "virtual firm"). A firm enters the panel after it is founded. We used firm web sites or resources such as CorpTech and other archival listings of firms. For firms where we could not find a birth date (less than $10 \%$ of the total, and only small firms), we make the uniform assumption that the firm was born two years prior to its first ATP 
participation (see Tables 1 and A2 for births post-1988 entry/birth data). It would be ideal to also clean for firm death, but we did not have sufficient information. We assumed that universities and other non-profits existed throughout the period; once again, our information was too sparse to check this except for universities (and all existed throughout the panel).

Step 4: Determine "Patenting Entities" that Changed Identity With Merger/Acquisition

We used the SDC merger and acquisitions database, coupled with firms' web sites, to determine the date of acquisition 1988 to 1997, and then determined if the "patenting entity" remained the same after the acquisition/merger or changed. Those that did not change required no adjustment, but those that did meant that we merged the two company patenting records from the beginning of the panel or founding (if later) in order to track the same entity over time. We cannot determine exactly which patents published after the purchase or attributable to the acquired firm, and which patents are attributable to the acquiring firm. In some cases this means we also modify the birth year for this ATP parent. Table A3 presents these data, showing the total number of mergers and acquisitions and then breaking out the number that still patent under their "old" name and the number that do not—but patent under the new parent name. Among new "patenting entity" parents, it is interesting to note that a sizeable proportion were also ATP recipients, suggesting an interesting question for further research.

\section{Deflated Patents}

Our framework for analysis of ATP effects rests on measurement of changes in patent applications made by companies (for patents that are later granted) during the period they are active ATP participants and are receiving ATP funding.

The overall rate of patenting is affected by the value of patents and the ease of obtaining them (Griliches, 1992). In recent years Congress and the courts have strengthened patent rights and the U.S. Patent and Trademark Office has hired more patent examiners. As a result, both the 
rate of patent application and the speed with which patents are granted have increased. Thus, a simple before and after comparison is subject to criticism as reflecting trend increases rather than any real effect.

Accordingly, we developed a "deflated" patent-count measure, which corrects for yearto-year changes in the average number of patents issued to all U.S. assignees of U.S. patents. We use 1996 as our base year. If there were 2.0 patents per assignee in 1996 and 2.4 patents per assignee in some other year, firms in our sample that increased by $20 \%$ in that year compared to the base year would show no change in deflated patents. A firm would have to have 1.32 times as many patents to be credited with a $10 \%$ increase $(1.32 / 1.2=1.1)$ and a firm that increased patenting by $10 \%$ would be credited with an $8.3 \%$ decrease in deflated patents $(1.1 / 1.2=0.917)$. - Figure A3 reports data by application year on the total number of U.S. patents granted (up to June 30, 1999) with a U.S. assignee at issue and the corresponding deflated patents. Note that the values for 1996 and 1997 show that our procedure also corrects for truncation problems. Zucker, and Darby (2003) discuss the deflation procedure in detail and examine several alternative deflators.

Figure A4 shows that our method of deflation does not alter the basic comparison of patenting rates before and after ATP participation. Deflation is preferred to including year dummies in our regression analysis because the logged form of the equation (required to use year dummies for widely different sized firms) requires us to make the implausible assumption that a \$2 million ATP award has the same percentage effect on patenting in a 10-person startup firm and large technology firms with hundreds of patents per year.

\section{A.3. Variable Construction}

To construct panel data, all of the ATP program variables were divided into monthly 
proportions, and then summed for the given year. For continuous variables, such as firm ATP award, this entailed first dividing the money that the firm is awarded into monthly allocations based on the duration of the project. If a firm is in more than one project in any given month, then the firm's amount for that the month is the sum of the monthly allocation for these separate projects. For ratio variables, such as ATP participation, we started by creating dummy variables for each month. For instance, if a firm is in the ATP in March 1994 we give it a value of one for ATP participation for that month. This value is always zero or one, regardless of how many projects the firm is in simultaneously. We then sum these monthly dummy variables for each year, and divide by 12, thus getting the fraction of the year that the firm is an ATP participant.

More generally: Some ATP organizations are in multiple projects, which means all the organization's separate involvements are consolidated when they overlap within the same year. For example, the award amount variable in 1995 for a firm in two simultaneous projects in that year is the sum of the money given to the firm in both projects that year. This also means, for instance, that a single observation can be both a single applicant and a JV member in any given year.

The unit of observation in the panels is the firm/year, but we construct those variables from monthly observations because ATP projects are started throughout the year. With this method, therefore, we do not overvalue ATP variables for a firm in 1995 whose project did not start until November. For example, the values of ATP variables for this firm would be one sixth (2 months/12) of their value if the firm were involved in the program all 12 months in the year.

We convert dollar amounts (i.e., the ATP and JV award dollars, as well as R\&D expenditures for public firms) to 1996 dollars by dividing by the Bureau of Economic Analysis's Chain-type Price Index for Gross Domestic Product $(1996=1.000)$ downloaded from the BEA site on July 17, 2000. 


\section{A.4. Data Sources}

The data used in this paper come from a variety of sources, all of which except the NIST web site are "limited use" data licensed specifically to UCLA or to Zucker and Darby as Principal Investigators. Data about Advanced Technology Program (ATP) participants and projects was provided by Jeanne W. Powell at ATP (limited use data) and from our own data collection from the NIST web site. We used COMPUSTAT data for firm R\&D expenditures. Our patent data (patent applications for eventually granted patents) come from two different sources: Hall, Jaffe, and Tratjenberg (2001) patent database through 1996 and from the UCLACISTCUP patent files for 1997-June 1999. To track individual companies over time, we used data on year of founding and identity of corporate parent, as well as dates of mergers and acquisitions, from three major data series under separate license to UCLA from the Securities Data Corporation (SDC), two supported by UC and CISTCP at UCLA and one supported by ATP/NIST.

\section{A.5. Additional Empirical Results}

\section{Chi-squared Tests for Constrained Coefficients in Tables 5-8}

Table A4 presents the $\chi^{2}$ tests for the hypothesis that both the coefficient of the ATP award and the coefficient of the ATP participant are simultaneously equal to zero in the regressions reported in Tables 5-8. In every case this hypothesis is rejected at the 0.001 confidence level providing evidence that even where the signs are in opposite directions the net impact of involvement in ATP is significantly different from 0.

Table A4 also presents the $\chi^{2}$ tests for the hypothesis that the coefficient of the ATP award, the coefficient of the ATP participant, the coefficient of the JV award, and the coefficient 
of the JV participant variables are all four simultaneously equal to zero in the regressions reported in Tables 5-8 which contain all 4 variables. Here the results are mixed: In the structural equations the joint hypothesis is again rejected at the 0.001 confidence level. In the Fixed effects models, dropping all four variables does not increase the sum of squared residuals by a statistically significant amount.

Estimates for Patenting by All Participants including Non-profit Organizations

Table A5 compares the descriptive statistics for the panel including all organizations participating in ATP with those for the all firms and public firm panels (compare Table 3). Table A6 estimates the results for the full sample (including university and non-profit participants) and suggests that the full sample is rather like that for all firms.

\section{Tobit Regressions}

We experimented with Tobit regressions as a way to deal with truncation at zero so that firms either patent so many times or not at all. The results in Table A7 are similar to the panel and fixed effects regressions reported in the text and more difficult to interpret. Regressions A7.1 and A7.2 are the controls only and full Tobit regressions for the all firms sample. Regressions A7.3 and A7.4 and regressions A7.5 and A7.6 are the corresponding regressions for the public firms and all organizations samples, respectively. 


\section{A.6. Additional References for the Technical Appendix}

Griliches, Zvi. "The Search for R\&D Spillovers." Scandinavian Journal of Economics, 94(Supplement), 1992, 29-47.

Powell, Jeanne W. Development, Commercialization, and Diffusion of Enabling Technologies, Progress Report for Projects Funded 1993-1995. Advanced Technology Program, U.S. National Institute of Standards and Technology NISTIR 6098, December 1997.

Zucker, Lynne G., and Michael R. Darby. "Measuring Success of ATP Participation Using Archival Data." Report to the Economic Assessment Office, Advanced Technology Program, National Institute of Standards and Technology, U.S. Department of Commerce, January 8, 2003. 
TABLE A1

Analysis Sampling Criteria

ATP participants selected for analysis meet the following criteria:

1. Companies only first, then add Universities \& non-profits.

2. Involved in ATP sponsored research and development.

3. Not involved in projects cancelled before completion.

4. Involved in a project that started work by $12 / 31 / 1995$.

5. Observation years are from 1988 or the birth year of the organization, whichever is greatest, to 1996.

6. Patent data has a one-year lead, so patent observations are from 1989 to 1997.

TABLE A2

ATP Active Organizations (Firms, Universities and Other Non-profits) by Panel Year

\begin{tabular}{lccccccccc}
\hline Year & 1988 & 1989 & 1990 & 1991 & 1992 & 1993 & 1994 & 1995 & 1996 \\
\hline Total Organizations & 294 & 307 & 322 & 336 & 347 & 411 & 411 & 412 & 412 \\
Entrants to Panel & 294 & 13 & 15 & 14 & 11 & 64 & 0 & 1 & 0 \\
Active in ATP & 0 & 0 & 0 & 25 & 89 & 111 & 138 & 403 & 377 \\
Inactive in ATP & 294 & 307 & 322 & 311 & 258 & 300 & 273 & 9 & 35 \\
\hline
\end{tabular}

TABLE A3

ATP Firms Acquired by Another Firm during Study Period

\begin{tabular}{ccccc}
\hline Year & $\begin{array}{l}\text { Total no. of } \\
\text { ATP firms } \\
\text { acquired }^{\text {a }}\end{array}$ & $\begin{array}{l}\text { ATP firms acquired but } \\
\text { still patenting } \\
\text { independently }\end{array}$ & $\begin{array}{l}\text { ATP firms acquired } \\
\text { by another ATP firm }\end{array}$ & $\begin{array}{l}\text { ATP firms acquired } \\
\text { by a non-ATP firm } \\
\text { and not patenting } \\
\text { independently }\end{array}$ \\
\hline 1991 & 2 & 2 & 0 & 0 \\
1992 & 3 & 2 & 0 & 1 \\
1993 & 3 & 2 & 0 & 1 \\
1994 & 2 & 1 & 1 & 0 \\
1995 & 5 & 4 & 1 & 0 \\
1996 & 8 & 5 & 2 & 7 \\
$1997^{\text {b }}$ & 15 & 5 & 3 & 7 \\
\hline
\end{tabular}

${ }^{a}$ Firms in the analysis sample only. Firms that first start ATP after 1995 are not included in this summary.

${ }^{\mathrm{b}}$ The dependent variable, patent application count, has a one year lead time. Therefore, although the panel ends in 1996, merger and acquisition activity in 1997 is relevant. 
TABLE A4

Chi-Squared Tests for Participation Coefficients of Regressions in Tables 5-8

Panel A - Patenting by All Firms: Intensity of ATP Project Participation - OLS Regression

Dependent Variable

Patent application count for following year (for patents ultimately granted only), US patents/US assignees deflator

Specification 5.1

5.2

5.3

5.4

Estimation

OLS

OLS

OLS

OLS

$\mathrm{P}^{2}(2)$ test for coefficients of ATP award

$\mathrm{n} / \mathrm{a}$

$260.90 * * *$

$151.14 * * *$

$130.96^{* * *}$

\& ATP participant both $=0$

$\mathrm{P}^{2}(2)$ test for coefficients of ATP award

$\mathrm{n} / \mathrm{a}$

$\mathrm{n} / \mathrm{a}$

$80.86^{* * *}$

$57.58 * * *$

$+\mathrm{JV}$ award $=0$ and coefs. of ATP

participant $+\mathrm{JV}$ participant $=0$

Panel B - Patenting by All Firms: Intensity of ATP Project Participation - Fixed Effects

Dependent Variable

Patent application count for following year (for patents ultimately granted only), US patents/US assignees deflator

Specification

6.1

Fixed effects

Estimation

$\mathrm{P}^{2}(2)$ test for coefficients of ATP

award \& ATP participant both $=0$

$P^{2}(2)$ test for coefficients of ATP

award $+\mathrm{JV}$ award $=0$ and coefs. of

ATP participant + JV participant $=0$

Panel C - Patenting by Public Firms: Intensity of ATP Project Participation - OLS Regression

Dependent Variable

Patent application count for following year (for patents ultimately granted only), US patents/US assignees deflator

Specification

Estimation

7.1

OLS

$\mathrm{n} / \mathrm{a}$

2.16

0.22
6.3 Fixed effects
OLS

OLS

7.4

OLS

$P^{2}(2)$ test for coefficients of ATP
award \& ATP participant both $=0$

$P^{2}(2)$ test for coefficients of ATP

$\mathrm{N} / \mathrm{a}$

$53.14 * * *$

$102.58 * * *$

$77.86^{* * *}$

award $+\mathrm{JV}$ award $=0$ and coefs. of

ATP participant $+\mathrm{JV}$ participant $=0$

Panel D - Patenting by Public Firms: Intensity of ATP Project Participation - Fixed Effects

Dependent Variable

Patent application count for following year (for patents ultimately granted only), US patents/US assignees deflator

Specification

8.1

8.2

8.3

Estimation

Fixed effects

Fixed effects

Fixed effects

$\mathrm{P}^{2}(2)$ test for coefficients of ATP

$20.88^{* * *}$

$50.20 * * *$

$49.02 * * *$

award \& ATP participant both $=0$

$P^{2}(2)$ test for coefficients of ATP

$\mathrm{n} / \mathrm{a}$

3.94

1.48

award $+\mathrm{JV}$ award $=0$ and coefs. of

ATP participant + JV participant $=0$

Significance levels for all four panels: $* \mathrm{p} \leq .05, * * \mathrm{p} \leq .01, * * * \mathrm{p} \leq .001$ 
TABLE A5

Descriptive Statistics for All ATP Participants

\begin{tabular}{|c|c|c|c|c|c|c|}
\hline \multirow[b]{2}{*}{ Variable } & \multicolumn{2}{|c|}{ All Firms } & \multicolumn{2}{|c|}{ Public Firms } & \multicolumn{2}{|c|}{$\frac{\text { All }}{\underset{\mathrm{Organizations}}{\mathrm{N}=3252}}$} \\
\hline & Mean & S. D. & Mean & S. D. & Mean & S. D. \\
\hline DEPENDENT VARIABLE & & & & & & \\
\hline Patent applications/US assignees deflator ${ }^{\mathrm{e}}$ & 39.35 & 141.83 & 87.37 & 206.93 & 34.59 & 130.14 \\
\hline PARTICIPATION INDICATORS & & & & & & \\
\hline ATP participant ${ }^{b}$ & 0.29 & 0.42 & 0.33 & 0.44 & 0.28 & 0.42 \\
\hline ATP JV participant ${ }^{b}$ & 0.20 & 0.37 & 0.26 & 0.42 & 0.21 & 0.38 \\
\hline JV with University partner ${ }^{\mathrm{b}}$ & 0.08 & 0.26 & 0.12 & 0.31 & 0.11 & 0.29 \\
\hline JV with Univ. subcontractor ${ }^{b}$ & 0.11 & 0.29 & 0.14 & 0.32 & 0.11 & 0.30 \\
\hline SP with Univ. subcontractor ${ }^{b}$ & 0.07 & 0.24 & 0.08 & 0.25 & 0.06 & 0.23 \\
\hline $\begin{array}{l}\text { Cum. ATP award stock, } \\
\quad(20 \% \text { annual depreciation, } \$ 000 \mathrm{~s})^{\text {a }}\end{array}$ & 272.39 & 748.74 & 389.78 & 1020.57 & 253.00 & 708.05 \\
\hline $\begin{array}{l}\text { Cum. ATP JV award stock, } \\
(20 \% \text { annual depreciation, } \$ 000 \mathrm{~s})^{\text {a }}\end{array}$ & 132.59 & 543.65 & 229.55 & 773.68 & 134.42 & 527.07 \\
\hline ORGANIZATION CHARACTERISTICS & & & & & & \\
\hline Small $^{\mathrm{c}}$ & 0.50 & 0.50 & 0.25 & 0.44 & 0.42 & 0.49 \\
\hline Medium $^{c}$ & 0.28 & 0.45 & 0.32 & 0.47 & 0.23 & 0.42 \\
\hline Large $^{c}$ & 0.22 & 0.41 & 0.43 & 0.49 & 0.18 & 0.39 \\
\hline Biotechnology ${ }^{d}$ & 0.13 & 0.32 & 0.11 & 0.30 & 0.13 & 0.32 \\
\hline Chemicals/Chemical Processing ${ }^{d}$ & 0.07 & 0.24 & 0.11 & 0.28 & 0.06 & 0.23 \\
\hline Electronics ${ }^{\mathrm{d}}$ & 0.14 & 0.32 & 0.14 & 0.30 & 0.13 & 0.30 \\
\hline Energy And Environment ${ }^{\mathrm{d}}$ & 0.04 & 0.18 & 0.05 & 0.19 & 0.03 & 0.17 \\
\hline $\begin{array}{l}\text { Information/Computers/Communication/Ent } \\
\text { ertainment System }{ }^{d}\end{array}$ & 0.23 & 0.41 & 0.21 & 0.39 & 0.26 & 0.42 \\
\hline Manufacturing (Discrete) ${ }^{\mathrm{d}}$ & 0.22 & 0.40 & 0.20 & 0.37 & 0.23 & 0.40 \\
\hline Materials ${ }^{d}$ & 0.17 & 0.35 & 0.18 & 0.34 & 0.15 & 0.34 \\
\hline $\begin{array}{l}\text { Cum. R\&D stock, } \\
\quad(20 \% \text { annual depreciation, \$millions })^{e}\end{array}$ & $\mathrm{~N} / \mathrm{a}$ & $\mathrm{n} / \mathrm{a}$ & 1759.78 & 4605.06 & $\mathrm{n} / \mathrm{a}$ & $\mathrm{n} / \mathrm{a}$ \\
\hline College ${ }^{\mathrm{c}}$ & $\mathrm{N} / \mathrm{a}$ & $\mathrm{n} / \mathrm{a}$ & $\mathrm{n} / \mathrm{a}$ & $\mathrm{n} / \mathrm{a}$ & 0.08 & 0.28 \\
\hline Other Non-Profit ${ }^{c}$ & $\mathrm{~N} / \mathrm{a}$ & $\mathrm{n} / \mathrm{a}$ & $\mathrm{n} / \mathrm{a}$ & $\mathrm{n} / \mathrm{a}$ & 0.09 & 0.29 \\
\hline
\end{tabular}

DEPENDENT VARIABLE

Patent applications/US assignees deflator ${ }^{\mathrm{e}}$

$\begin{array}{llllll}39.35 & 141.83 & 87.37 & 206.93 & 34.59 & 130.14\end{array}$

${ }^{a}$ continuous variable for org./year: sum of monthly awards for organization this year.

$\mathrm{b}$ (number of months during the year that the variable is true)/12; varies from 0 to 1 .

${ }^{c}$ dummy variable for organization: does not vary with year. Size categories defined for firms only.

d dummy variable for organization: does not vary with year. Industry (technology area) of ATP project; fractional proportion where organization is in more than one project where industry (technology area) differs.

${ }^{\mathrm{e}}$ continuous variable for organization/year. 
TABLE A6

Patenting by All ATP Organizational Participants - OLS Regression \& Fixed Effects

Dependent Variable

Specification

Estimation

Constant

Small

Large

College

Other Non-Profit

Biotechnology

Electronics

Energy And Environment

Info./Comp./Comm./Ent. System

Manufacturing (Discrete)

Materials

ATP participant

Cum. ATP award stock, (20\% annual depreciation, \$000s)

ATP JV participant

Cum. ATP JV award stock, (20\% annual depreciation, \$000s)

JV with University partner

JV with Univ. subcontractor

SP with Univ. subcontractor

$\mathbf{P}^{2}(2)$ test for coefficients of ATP

award \& ATP participant both $=0$

$\mathbf{P}^{2}(2)$ test for coefficients of ATP award $+\mathrm{JV}$ award $=0$ and coefs. of ATP participant + JV participant $=0$
Patent application count for following year (for patents ultimately granted only), US patents/US assignees deflator
A6.4

OLS Fixed Effects $\quad$ OLS $\quad$ Fixed Effects

\begin{tabular}{cccc} 
OLS & Fixed Effects & OLS & Fixed Effects \\
\hline$-38.756 * * *$ & $33.294 * * *$ & $-38.398 * * *$ & $33.234 * * *$ \\
$(9.305)$ & $(0.898)$ & $(9.319)$ & $(0.900)$ \\
$-11.506 *$ & & $-10.824 *$ & \\
$(5.023)$ & & $(5.014)$ & \\
$141.140 * * *$ & & $140.504 * * *$ & \\
$(6.155)$ & & $(6.143)$ & \\
11.885 & & 9.085 & \\
$(7.735)$ & & $(7.816)$ & \\
-8.227 & & -8.399 & \\
$(7.420)$ & & $(7.409)$ & \\
$45.970 * * *$ & & $46.016 * * *$ &
\end{tabular}

$46.016 * * *$
$(10.334)$

$76.316^{* * *}$

(10.366)

$38.353 * *$

(13.957)

$48.028 * * *$

(9.272)

$35.394 * * *$

(9.356)

$40.932 * * *$

(9.947)

$-96.880 * * *$

$(10.368)$

$0.092 * * *$

$(0.007)$

$96.456^{* * *}$

(11.273)

$-0.057^{* * *}$

(0.009)
(10.382)

$79.829 * * *$

(10.421)

$38.215 * *$

(13.932)

$47.270 * * *$

(9.309)

$34.048 * * *$

(9.357)

$41.013 * * *$

(9.939)

$-25.453 * * * \quad-109.492 * * *$

$-25.799 * * *$

(11.646)

$0.084 * * *$

(5.145)

$0.032 * * *$

(0.003)

$22.310 * * *$

(0.007)

$85.996 * * *$

(14.026)

$-0.050 * * *$

$-0.031 * * *$

(0.004)

$(0.009)$

23.286*

(9.182)

$19.589^{*}$

(9.102)

$30.375^{*}$

(12.767)

$191.58 * * *$

$100.24 * * *$

$167.36 * * *$

$84.24 * * *$

1.70

$62.10 * * *$
$0.032 * * *$

(0.003)

$25.738 * * *$

(6.453)

$-0.031 * * *$

(0.004)

1.875

(4.282)

$-7.505$

(4.316)

0.744

(5.938)

\begin{tabular}{lcccc}
\hline Adjusted R-squared & $0.314 * * *$ & $0.899 * * *$ & $0.318 * * *$ & $0.899 * * *$ \\
$\mathrm{~N}$ & 3252 & 3252 & 3252 & 3252 \\
\hline
\end{tabular}

Significance levels: $* \mathrm{p} \leq .05, * * \mathrm{p} \leq .01, * * * \mathrm{p} \leq .001$ 


\section{TABLE A7}

\section{Selected Tobit Regressions for Patenting by ATP Participants}

Dependent Variable Patent application count for following year (for patents ultimately granted only), US patents/US assignees deflator

\begin{tabular}{|c|c|c|c|c|c|c|}
\hline \multirow{3}{*}{$\begin{array}{l}\text { Specification } \\
\text { Estimation }\end{array}$} & \multicolumn{2}{|c|}{ All Firms } & \multicolumn{2}{|c|}{ Public Firms } & \multicolumn{2}{|c|}{ All Organizations } \\
\hline & A7.1 & A 7.2 & A7.3 & A7.4 & A7.5 & A7.6 \\
\hline & Tobit & Tobit & Tobit & Tobit & Tobit & Tobit \\
\hline Constant & $\begin{array}{c}-123.576^{* * * *} \\
(17.185)\end{array}$ & $\begin{array}{c}-108.821 * * * \\
(16.152)\end{array}$ & $\begin{array}{c}-127.008 * * * \\
(24.369)\end{array}$ & $\begin{array}{c}-114.169 * * * \\
(23.367)\end{array}$ & $\begin{array}{c}-119.759 * * * \\
\quad(15.552)\end{array}$ & $\begin{array}{c}-105.723 * * * \\
(14.675)\end{array}$ \\
\hline Small & $\begin{array}{c}-91.899 * * * \\
(9.598)\end{array}$ & $\begin{array}{c}-88.128 * * * \\
(9.053)\end{array}$ & $\begin{array}{c}-62.888 * * * \\
(16.593)\end{array}$ & $\begin{array}{c}-65.121 * * * \\
(16.057)\end{array}$ & $\begin{array}{c}-83.742 * * * \\
(8.717)\end{array}$ & $\begin{array}{c}-80.896 * * * \\
(8.260)\end{array}$ \\
\hline Large & $\begin{array}{c}214.712 * * * \\
\quad(10.375)\end{array}$ & $\begin{array}{l}188.673 * * * \\
(9.850)\end{array}$ & $\begin{array}{l}159.385 * * * \\
(15.102)\end{array}$ & $\begin{array}{l}150.447 * * * \\
(14.405)\end{array}$ & $\begin{array}{l}212.162 * * * \\
(9.447)\end{array}$ & $\begin{array}{l}187.830 * * * \\
(9.000)\end{array}$ \\
\hline Biotechnology & $\begin{array}{c}111.546 * * * \\
(19.756)\end{array}$ & $\begin{array}{c}89.842 * * * \\
(18.704)\end{array}$ & $\begin{array}{l}135.643 * * * \\
(29.242)\end{array}$ & $\begin{array}{c}130.881 * * * \\
(28.241)\end{array}$ & $\begin{array}{c}103.681 * * * \\
(17.385)\end{array}$ & $\begin{array}{c}84.559 * * * \\
(16.485)\end{array}$ \\
\hline Electronics & $\begin{array}{l}181.755 * * * \\
\quad(19.274)\end{array}$ & $\begin{array}{l}152.260 * * * \\
\quad(18.485)\end{array}$ & $\begin{array}{l}223.177 * * * \\
\quad(28.740)\end{array}$ & $\begin{array}{l}203.665 * * * \\
\quad(28.312)\end{array}$ & $\begin{array}{c}179.371 * * * \\
(17.284)\end{array}$ & $\begin{array}{c}147.366 * * * \\
(16.615)\end{array}$ \\
\hline Energy And Envt. & $\begin{array}{c}126.169 * * * \\
(25.020)\end{array}$ & $\begin{array}{c}107.339 * * * \\
(23.488)\end{array}$ & $\begin{array}{l}112.230 * * * \\
(34.470)\end{array}$ & $\begin{array}{l}96.332 * * \\
(33.181)\end{array}$ & $\begin{array}{c}115.978 * * * \\
(22.389)\end{array}$ & $\begin{array}{c}95.650 * * * \\
(21.129)\end{array}$ \\
\hline $\begin{array}{l}\text { Info./Comp./ } \\
\text { Comm./Ent. System }\end{array}$ & $\begin{array}{l}54.700 * * \\
(17.691)\end{array}$ & $\begin{array}{l}39.766^{*} \\
(16.706)\end{array}$ & $\begin{array}{l}89.654 * * * \\
(24.434)\end{array}$ & $\begin{array}{l}85.006 * * * \\
(23.641)\end{array}$ & $\begin{array}{l}51.099 * * * \\
(15.734)\end{array}$ & $\begin{array}{l}37.719 * \\
(14.894)\end{array}$ \\
\hline Manufacturing & $\begin{array}{c}24.445 \\
(17.926)\end{array}$ & $\begin{array}{c}9.946 \\
(16.916)\end{array}$ & $\begin{array}{l}-28.215 \\
(25.162)\end{array}$ & $\begin{array}{l}-26.404 \\
(24.095)\end{array}$ & $\begin{array}{l}37.714^{*} \\
(15.890)\end{array}$ & $\begin{array}{c}26.208 \\
(14.986)\end{array}$ \\
\hline Materials & $\begin{array}{c}60.924 * * * \\
(18.956)\end{array}$ & $\begin{array}{l}46.322 * * \\
(17.805)\end{array}$ & $\begin{array}{c}99.207 * * * \\
(26.863)\end{array}$ & $\begin{array}{c}84.866 * * * \\
(25.637)\end{array}$ & $\begin{array}{c}57.926 * * * \\
(16.953)\end{array}$ & $\begin{array}{l}44.836^{* *} \\
(15.974)\end{array}$ \\
\hline $\begin{array}{l}\text { R \& D Stock } \\
\quad(\$ \text { millions })\end{array}$ & & & $\begin{array}{c}2.751 * * * \\
(0.153)\end{array}$ & $\begin{array}{l}2.501 * * * \\
(0.158)\end{array}$ & & \\
\hline College & & & & & $\begin{array}{l}55.024 * * * \\
(11.871)\end{array}$ & $\begin{array}{c}50.196 * * * \\
(11.373)\end{array}$ \\
\hline Non-Profit & & & & & $\begin{array}{c}-82.250 * * * \\
(13.936)\end{array}$ & $\begin{array}{l}-84.180 * * * \\
\quad(13.176)\end{array}$ \\
\hline $\begin{array}{l}\text { Cum. ATP \$ stock, } \\
(20 \% \text { anl dep, } \$ 000 \text { s })\end{array}$ & & $\begin{array}{c}0.094 * * * \\
(0.012)\end{array}$ & & $\begin{array}{c}0.098 * * * \\
(0.015)\end{array}$ & & $\begin{array}{c}0.094 * * * \\
(0.011)\end{array}$ \\
\hline ATP participant & & $\begin{array}{l}-94.001 * * * \\
(19.916)\end{array}$ & & $\begin{array}{l}-135.534 * * * \\
\quad(30.417)\end{array}$ & & $\begin{array}{c}-97.146 * * * \\
(18.087)\end{array}$ \\
\hline ATP JV participant & & $\begin{array}{c}-0.052 * * * \\
(0.015)\end{array}$ & & $\begin{array}{c}-0.094 * * * \\
(0.019)\end{array}$ & & $\begin{array}{c}-0.054 * * * \\
(0.013)\end{array}$ \\
\hline $\begin{array}{l}\text { Cum. ATP JV \$ stock } \\
(20 \% \text { anl dep, } \$ 000 \text { s })\end{array}$ & & $\begin{array}{l}41.240 \\
(24.864)\end{array}$ & & $\begin{array}{l}90.435^{*} \\
(36.602)\end{array}$ & & $\begin{array}{l}58.565^{* *} \\
(22.086)\end{array}$ \\
\hline JV with Univ. partner & & $\begin{array}{c}61.700 * * * \\
(17.413)\end{array}$ & & $\begin{array}{c}29.441 \\
(23.405)\end{array}$ & & $\begin{array}{l}39.947 * * \\
(14.420)\end{array}$ \\
\hline $\begin{array}{l}\text { JV with Univ. } \\
\text { Subcontractor }\end{array}$ & & $\begin{array}{l}48.397 * * \\
(17.830)\end{array}$ & & $\begin{array}{c}29.155 \\
(24.376)\end{array}$ & & $\begin{array}{c}26.768 \\
(14.345)\end{array}$ \\
\hline $\begin{array}{l}\text { SP with Univ. } \\
\text { Subcontractor }\end{array}$ & & $\begin{array}{c}7.307 \\
(21.807) \\
\end{array}$ & & $\begin{array}{c}26.677 \\
(33.851) \\
\end{array}$ & & $\begin{array}{c}16.184 \\
(19.871) \\
\end{array}$ \\
\hline $\begin{array}{l}\mathrm{P}^{2}: \text { ATP Award }=0 \text { and } \\
\text { ATP participation }=0\end{array}$ & & $69.48 * * *$ & & $54.64 * * *$ & & $86.86 * * *$ \\
\hline $\begin{array}{l}\mathrm{P}^{2}: \text { ATP Award - JV } \\
\text { Award }=0 \text { and ATP } \\
\text { part. - JV part. }=0\end{array}$ & & $36.70 * * *$ & & 4.06 & & $43.32 * * *$ \\
\hline $\begin{array}{l}\text { Log Likelihood } \\
\mathrm{N}\end{array}$ & $\begin{array}{c}-9959.33 * * * \\
2694 \\
\end{array}$ & $\begin{array}{c}-9859.90 * * * \\
2694 \\
\end{array}$ & $\begin{array}{c}-5549.21 * * * \\
1067 \\
\end{array}$ & $\begin{array}{c}-5509.00 * * * \\
1067 \\
\end{array}$ & $\begin{array}{c}-11868.63^{* * *} \\
3252 \\
\end{array}$ & $\begin{array}{c}-11757.24 * * * \\
3252 \\
\end{array}$ \\
\hline
\end{tabular}

Significance levels: $* \mathrm{p} \leq .05, * * \mathrm{p} \leq .01, * * * \mathrm{p} \leq .001$ 


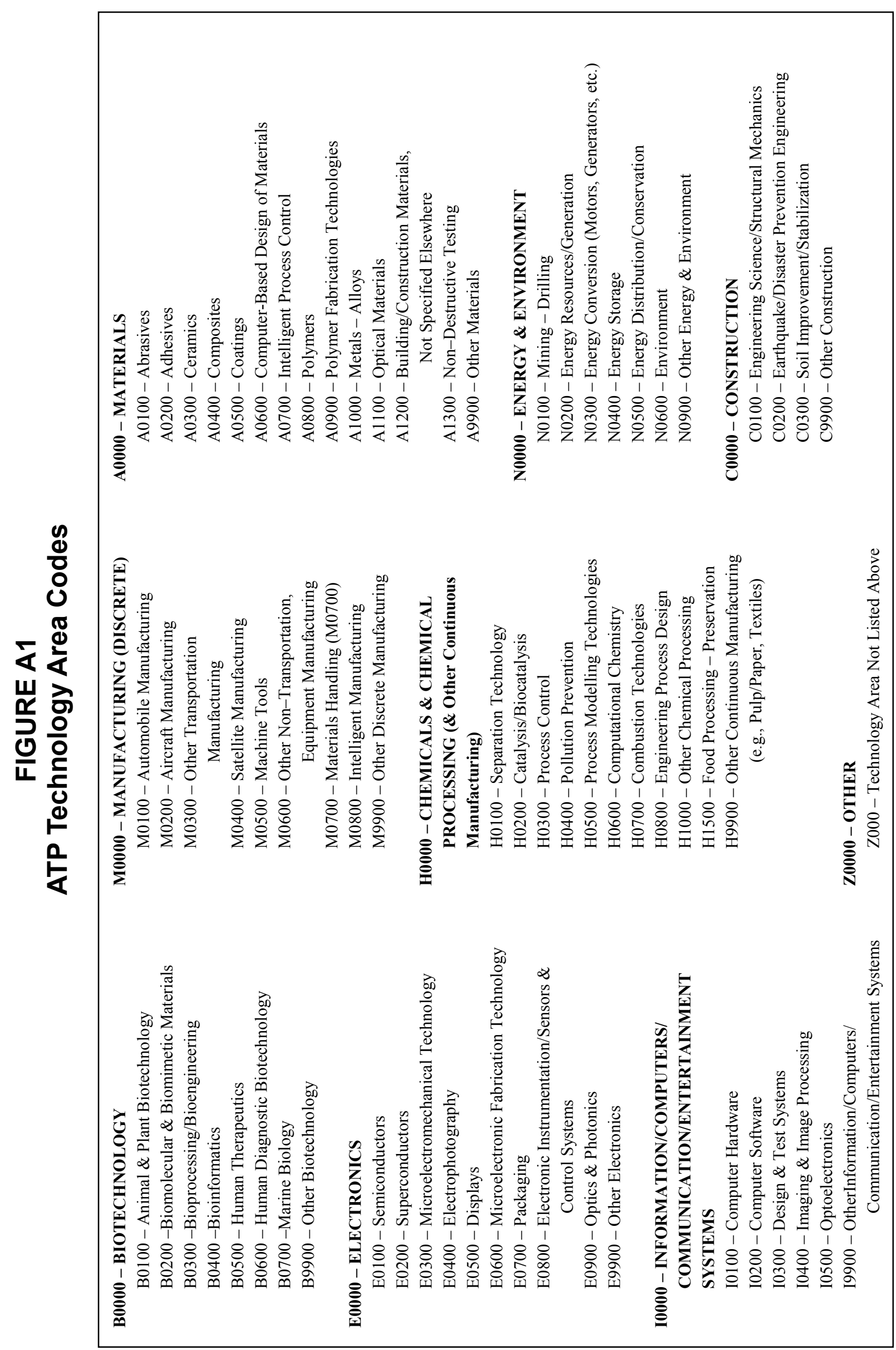




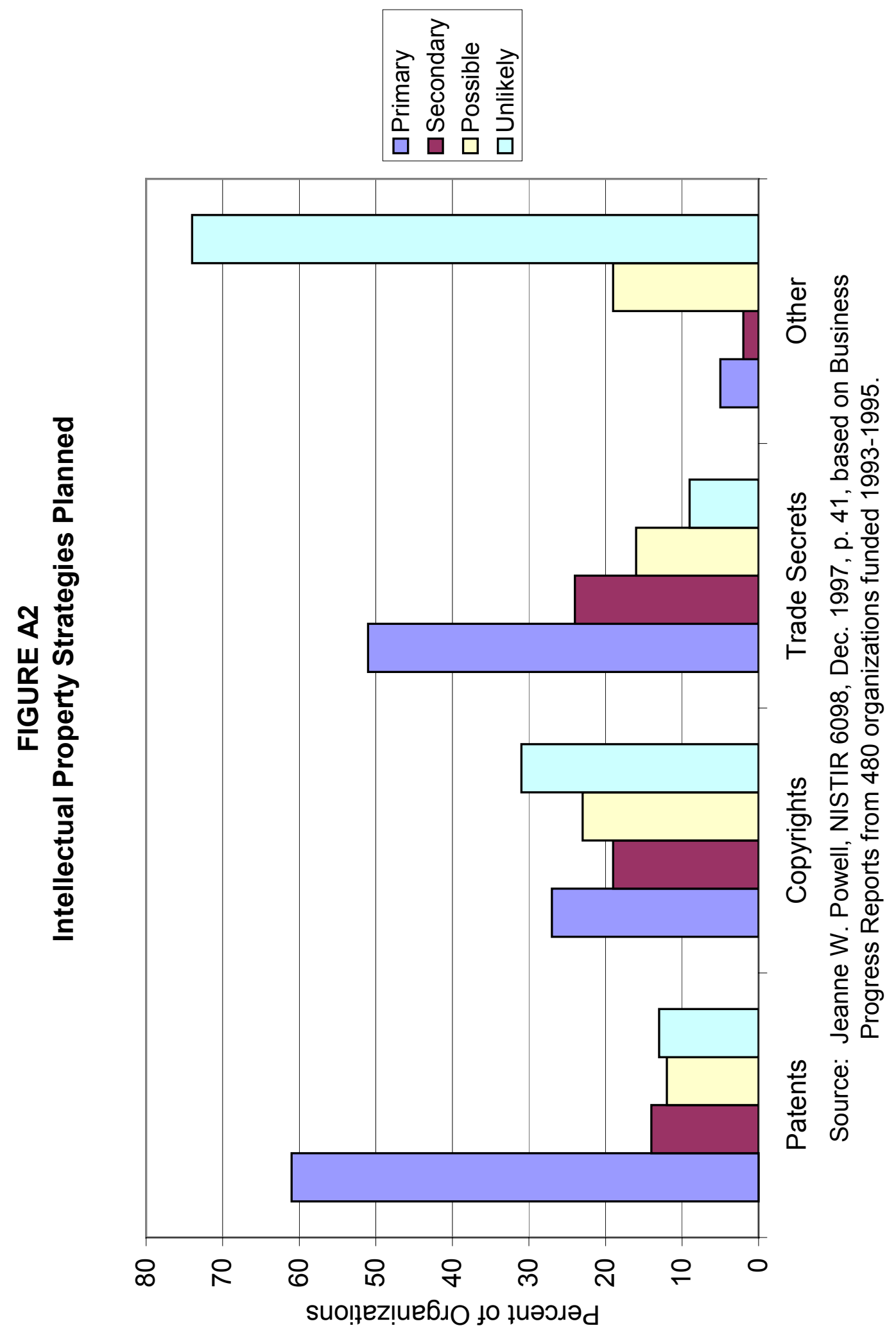




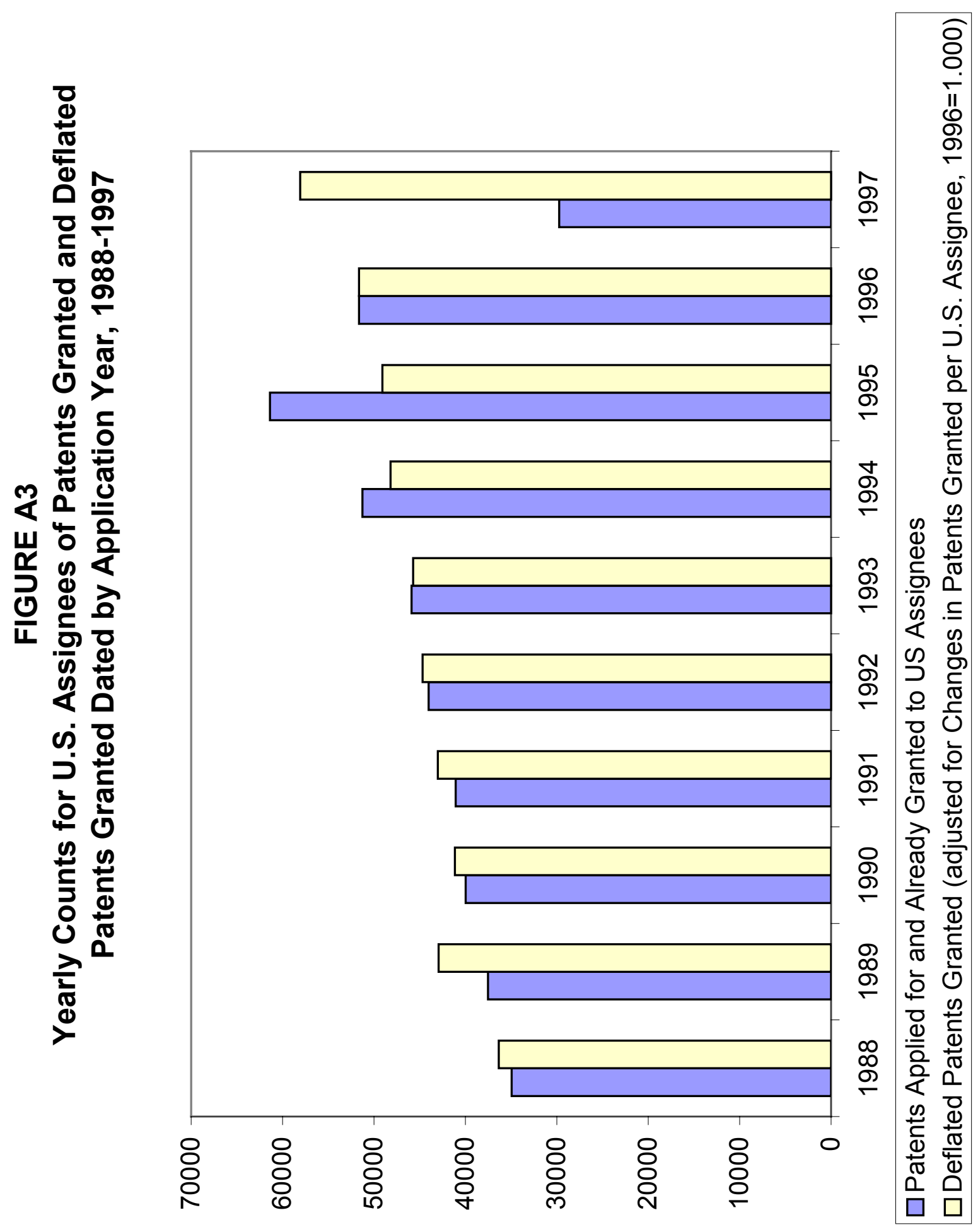




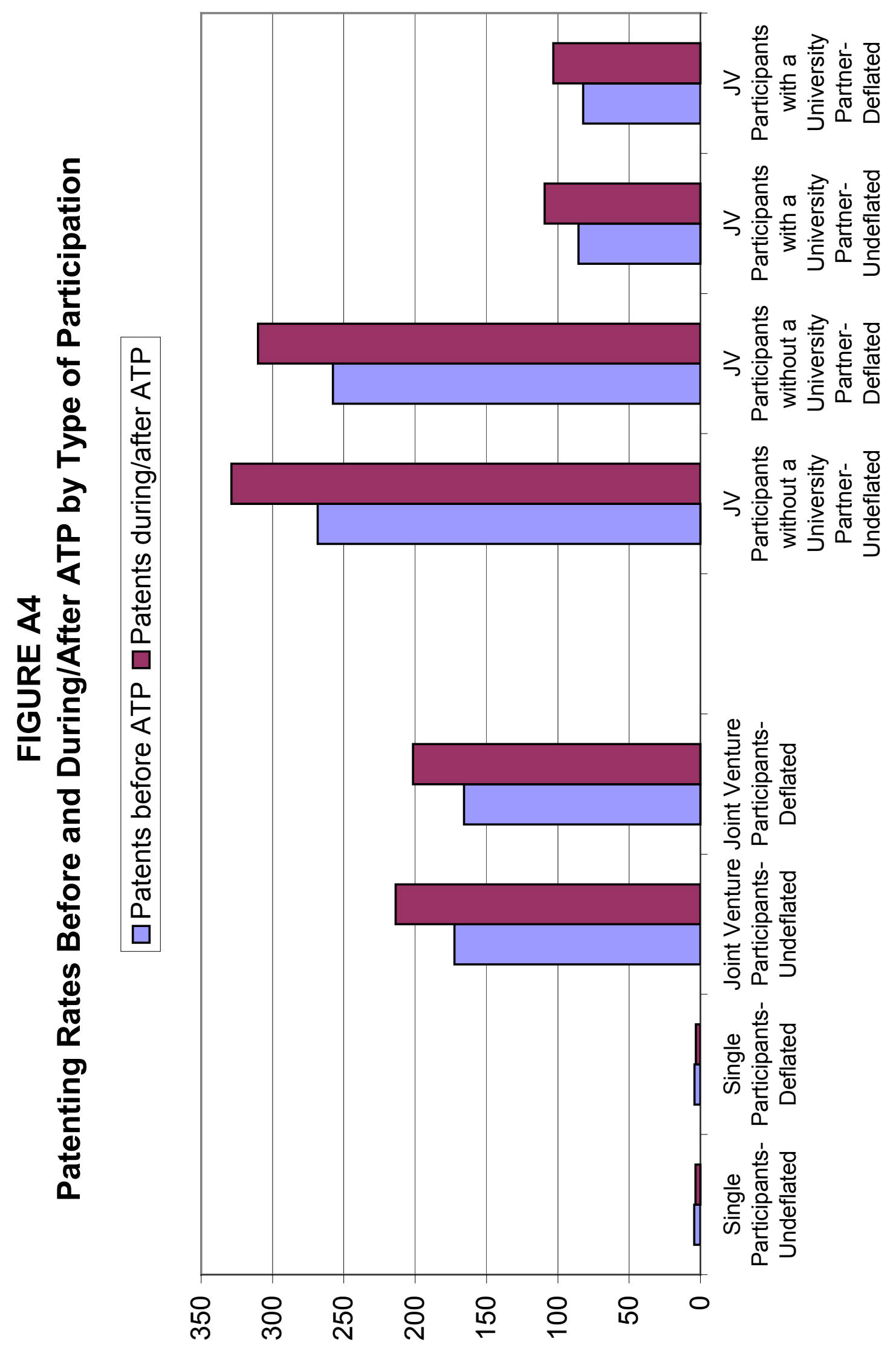

